INEL-95/0055

\title{
Calculations of Protective Action Distance for Toxic Chemical Spills Using Nomographs
}

L. G. Lee

J. A. Vail

G. L. Gibeault

Published April 1995

Idaho National Engineering Laboratory Nuclear Engineering Department Lockheed Idaho Technologies Company Idaho Falls, Idaho 83415

Prepared for the

U.S. Department of Energy

Assistant Secretary for Environmental Management

Under DOE Idaho Operations Office

Contract DE-AC07-94ID13223

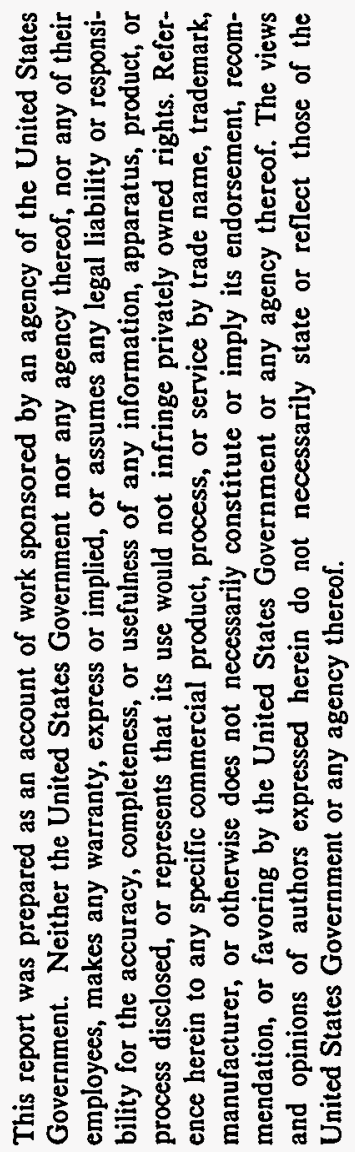




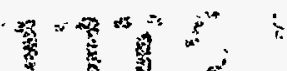

$\therefore$ 的等 


\section{DISCLAIMER}

Portions of this document may be illegible in electronic image products. Images are produced from the best available original document. 
CONTENTS

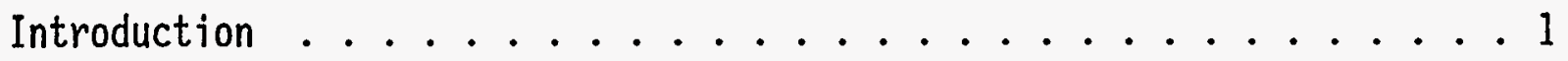

Input Data Needed for the Calculation . . . . . . . . . . 1

Instruction for Using the Nomographs ............

Instruction for Using the Nomographs ............ 1

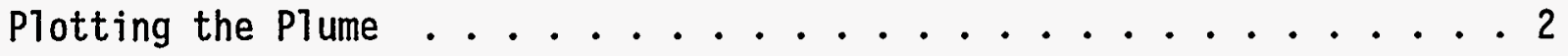

Appendix A Listing and Analysis of Limit Parameters Found for

88 Chemicals ................... 17

Appendix B Development of PTume Distance Nomograph

for Protective action ................ 25

Appendix C Acronym Definitions .............. 35

Appendix D Example Solutions of Nomographs ...........44

TABLES

Table 1 List of Chemicals for which Limit Parameters were Analyzed . . . 3

Table 2 Chemical Limits Based on ERPG or Hierarchy-based Alternative Concentrations ............... 6

Table 3 Widths of plume for each class of stability as a function of distance from source ............... 15

Table A-1 Chemical-Specific Primary or Hierarchy-based Alternative Concentrations ........... 21

Table A-2 Recommended Hierarchy of Alternative Concentration-Limit Parameters................ 24

Table B-1. Nomograph Equations . . . . . . . . . . 28

Table B-2. Stability Equation and Constant Values ........ 30

\section{FIGURES}

Figure 1 Nomograph for toxic gas with daytime clear conditions . . . . 9

Figure 2 Nomograph for toxic gas with day/night cloudy conditions . . 10

Figure 3 Nomograph for toxic gas with night clear conditions . . . . 11 
Figure 4 Nomograph for toxic liquid with daytime clear conditions . . 12

Figure 5 Nomograph for toxic liquid with day/night cloudy conditions . . 13

Figure 6 Nomograph for toxic liquid with night clear conditions . . 14

Figure 7 Plume size based on stability ............ 15

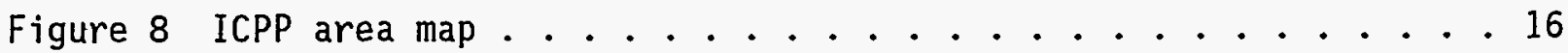

Figure B-1 Protective action Plume Distance Nomograph . . . . . 32 


\section{Introduction}

This document was produced for emergency use following a spill of liquid gas or finely divided solid ( $<100$ micron) toxic chemicals. The information on the next few pages was kept deliberately terse and is limited to data and graphic aids needed for calculation of plume distance (protective action distance). All supporting material is provided as Appendices.

\section{Input Data Needed for the Calculation}

The information needed for the calculation are:

Wind speed and direction

Area or flow rate of the spill

Identity of the chemica]

Sky conditions (Clear/Cloudy - Day/Night)

A11 other information can be found in Tables 1 and 2 .

The chemicals listed in Tables 1 and 2 include all those for which ERPG, EEGLs, SPEGLs, and CEGLs vaTues have been published to date

Table 1 lists the vapor pressure and molecular weight for each chemical. Chemical formula and CAS Number are included for convenience.

Table 2 lists ERPG and PEL-TWA concentrations for a11 the chemicals found in Table 1.

\section{Instruction for Using the Nomographs}

Once the input data are collected, the nomographs can be used for calculation of plume distance. There two sets of nomographs. One set covers gas releases and finely divided solids (Figures 1,2 and 3) while the other set is used for liquid spills and boiling liquids (Figures 4,5 and 6 ):

There are three types of nomographs per set, one for each atmospheric stability class. The choice of which stability class selected, (based on sky conditions) determines the length of the center line of the chemical plume. "A" stability class "CLEAR DAY" is the first nomograph. The "D" stability class for day or night "CLOUDY-D/N" is second and "F" stability class "CLEAR NIGHT" is last. 
Referring to the liquid spill nomographs, merely mark the data points on the scales and connect these points with straight lines that overshoot the scales to the "tie lines".

- The wind speed value on the first left scale is connected to the molecular weight scale and this connecting line is extended to the tie line scale that has no numbers on it. This tie line was scaled down so the next scale could fit on the page. This scaling down is represented by the uniform 7 ines between this tie 7 ine and the next shorter parallel tie line.

- The next scale contains the range of vapor pressure values. A line is drawn from the scaled down tie line point through the proper vapor pressure value to the next tie line. This tie line has a scale down similar to the first one.

- From the second scaled down tie line point draw a line through the chemical airborne concentration (ERPG-2 is typically used for determining protective action distance) scale to the next tie line. This tie line did not need to be scaled down.

- In a similar manner, extend the line from the final tie line point through the area of the spill scale to plume distance scale and read the result.

The gas/solid aerosol nomographs are actually a simplified version of the Tiquid nomographs and are used the same way.

Examples of nomograph solutions are given in Appendix $D$ at the end of this document.

\section{Plotting the Plume}

Once the protective action distance is determined by use of the appropriate nomograph, the plume width can be determined from Table 3 or Figure 7 . The map of the area surrounding the site (Figure 8) may be used to determine the affected area. The plume plots (Figure 7) are printed to the same scale as the map ( $2 \mathrm{Km} / \mathrm{in})$ and can be used as an overlay if they are copied onto transparent overhead slide material. 
Table 1

List of Chemicals for which Limit Parameters were Analyzed

\begin{tabular}{|c|c|c|c|c|c|}
\hline CHEMICAL NAME & Chemical formula & $\begin{array}{l}\text { Physical } \\
\text { State }\end{array}$ & CAS NO. & $\begin{array}{l}\text { Vapor } \\
\text { Pressure } \\
\text { (mm/Hg) }\end{array}$ & $\begin{array}{l}\text { Molecular } \\
\text { Height }\end{array}$ \\
\hline Acetone & $\mathrm{CH} 3 . \mathrm{CO} . \mathrm{CH} 3$ & $\mathbf{L}$ & $67-64-1$ & 180 & 58.1 \\
\hline Acrolein & $\mathrm{CH} 2=\mathrm{CHCHO}$ & $\mathrm{L}$ & $107-02-8$ & 210 & 56.1 \\
\hline Acrylic Acid & $\mathrm{H} 2 \mathrm{C}=\mathrm{CHCOOH}$ & $L$ & $79-10-7$ & 141 & 72.1 \\
\hline Acrylonitrile (Ca) & $\mathrm{CH} 2=\mathrm{CHCN}$ & 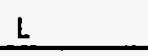 & $107-13-1$ & 83 & 53.1 \\
\hline Allyl Chloride & $\mathrm{CH} 2=\mathrm{CH} . \mathrm{CH} 2 . \mathrm{Cl}$ & $\mathbf{L}$ & $107-05-1$ & 295 & 76.5 \\
\hline Aluminum Oxide & Al203 & s & $1344-28-1$ & $\mathrm{NA}$ & 101.9 \\
\hline Ammonia & NH3 & G & $7664-41-7$ & 760 & 17.0 \\
\hline Arsenic (Inorganic) as As (Ca) & As inorg. cmpds. & $s$ & $7440-38-2$ & NA & 74.9 (AS) \\
\hline Arsenic (Organic compounds) as As & As org. cmpds. & s & $7440-38-2$ & $130-250$ & 74.9 (As) \\
\hline Arsine (Ca) & AsH3 & G & $7784-42-1$ & 760 & 77.9 \\
\hline Benzene(Ca) & $\mathrm{CGHG}$ & $\mathrm{L}$ & $71-43-2$ & 75 & 78.1 \\
\hline Beryllium (Ca) & $\mathrm{Be}$ & $s$ & $7440-41-7$ & NA & 9.0 \\
\hline Bromine & $\mathrm{Br}$ & $\mathbf{L}$ & $7726-95-6$ & 172 & 159.8 \\
\hline Bromotrifluoromethane & CBrF3 & G & $75-63-8$ & 760 & 148.9 \\
\hline 1,3 -Butadiene ( $\mathrm{Ca}$ ) & $\mathrm{CH} 2=\mathrm{CHCH}=\mathrm{CH} 2$ & G & $106-99-0$ & 760 & 54.1 \\
\hline Carbon Disulfide & $\operatorname{cs2}$ & $\mathrm{L}$ & $75-15-0$ & 297 & 76.1 \\
\hline Carbon Monoxide & co & G & $630-08-0$ & 760 & 28.0 \\
\hline Carbon Tetrachloride (Ca) & $\operatorname{ccl} 14$ & $L$ & $56-23-5$ & 91 & 153.8 \\
\hline Chlorine & $\mathrm{Cl2}$ & G & $7782-50-5$ & 760 & 70.9 \\
\hline Chlorine Trifluoride & ClF3 & $G>11.7 C$ & $7790-91-2$ & 760 & 92.5 \\
\hline Chloroacetyl Chloride & Cl.CH2.cocl & $L$ & $79-04-9$ & 45 & 113.0 \\
\hline Chloroform ( $\mathrm{Ca}$ ) & $\mathrm{CH} . \mathrm{Cl} 3$ & $L$ & $67-66-3$ & 160 & 119.4 \\
\hline Chloropicrin & C.Cl3. $\mathrm{NO2}$ & $L$ & $76-06-2$ & 20 & 164.4 \\
\hline Chlorosulfonic Acid & $\mathrm{Cl} . \mathrm{SO} . \mathrm{OH}$ & $L$ & $7790-94-05$ & & 116.5 \\
\hline Chlorotrifluoroethylene & $\mathrm{Cl} . \mathrm{FC}=\mathrm{CF} 2$ & G & $79-38-9$ & 760 & 116.5 \\
\hline Crotonaldehyde ( $\mathrm{Ca}$ ) & $\mathrm{CH} 3 . \mathrm{CH}=\mathrm{CHCHO}$ & $\mathbf{L}$ & $4170-30-3$ & & 70.1 \\
\hline Dichlorodifluoromethane (FC12) & C.C12.F2 & G & $75-71-8$ & 760 & 120.9 \\
\hline Dichlorofluoromethane (FC21) & CH.CL2.F & $G>8.9 \mathrm{C}$ & $75-43-4$ & 760 & 102.9 \\
\hline Dichlorotetrafluoroethane (FC114) & CF4.C.Cl2 & $G>3.8 \mathrm{C}$ & $76-14-2$ & 760 & 170.9 \\
\hline Diketene & $\mathrm{CH} 2=\mathrm{CC} \cdot \mathrm{H} 2 \cdot \mathrm{C}(\mathrm{O}) \mathrm{O}$ & $L$ & $674-82-8$ & & 84.1 \\
\hline Dimethylamine & (CH3)2.NH & G & $124-40-3$ & 760 & 45.1 \\
\hline Dimethyl formamide & HCON. $(\mathrm{CH} 3) 2$ & L & $68-12-2$ & 4 & 73.1 \\
\hline 1,1-D imethylhydrazine (Ca) & (CH3)2.NN.H2 & $\mathrm{L}$ & $57-14-7$ & 157 & 60.1 \\
\hline Epichlorohydrin ( $\mathrm{Ca}$ ) & C3.H5.O.Cl & L & $106-89-8$ & 13 & 92.5 \\
\hline
\end{tabular}




\begin{tabular}{|c|c|c|c|c|c|}
\hline CHEMICAL NAME & Chemical formula & $\begin{array}{l}\text { Physical } \\
\text { State }\end{array}$ & CAS NO. & $\begin{array}{l}\text { Vapor } \\
\text { Pressure } \\
\text { (mm/Hg) }\end{array}$ & $\begin{array}{l}\text { Molecular } \\
\text { Weight }\end{array}$ \\
\hline Ethanolamine & $\mathrm{NH} 2 . \mathrm{CH} 2 . \mathrm{CH} 2 . \mathrm{OH}$ & $L>10.6 C$ & $141-43-5$ & 0.4 & 61.1 \\
\hline Ethylene Glycol & $\mathrm{CH} 2 . \mathrm{OH} . \mathrm{CH} 2 . \mathrm{OH}$ & L & $107-21-1$ & & 62.1 \\
\hline Ethylene Oxide (Ca) & $\mathrm{CH} 2.0 . \mathrm{CH} 2$ & $G>10.6 C$ & $75-21-8$ & 760 & 44.1 \\
\hline Fluorine & $F 2$ & $\underline{G}$ & $7782-41-4$ & 760 & 38.0 \\
\hline Forma ldehyde (Ca) & НСНО & $G$ & $50-00-0$ & $760 \mathrm{G} / 1 \mathrm{Aq}$ & 30.0 \\
\hline Hexachlorobutadiene & $C L 2 . C=C . C l . C . C L=C . C L 2$ & $\mathrm{~L}$ & $87-68-3$ & & 260.8 \\
\hline Hydrazine (Ca) & $\mathrm{H} 2 . \mathrm{N}=\mathrm{N} . \mathrm{H} 2$ & $L$ & $302-01-2$ & 10 & 32.1 \\
\hline Hydrogen Chloride & $\mathrm{HCl}$ & $G$ & $7647-01-0$ & $760 / 42 \mathrm{Aq}$ & 36.5 \\
\hline Hydrogen Fluoride & HF & G & $7664-39-3$ & $760 / 130 \mathrm{Aq}$ & 20.1 \\
\hline Hydrogen Peroxide $(30 \%)$ & H2.02 & L & $7722-84-1$ & 5 & 34.0 \\
\hline Hydrogen Sulfide & $\mathrm{H} 2 . \mathrm{S}$ & L & $7783-06-4$ & 760 & 34.1 \\
\hline Isobutyronitrile & $(\mathrm{CH} 3) 2 . \mathrm{CH} \cdot \mathrm{CN}$ & $L$ & $78-82-0$ & 50 & 69.1 \\
\hline Isopropyl Alcohol & $(\mathrm{CH} 3) 2 . \mathrm{CH} . \mathrm{OH}$ & $L$ & $67-63-0$ & 33 & 601 \\
\hline Lithium Bromide & LiBr & $s$ & $7550-35-8$ & NA & 869 \\
\hline Lithium Chromate & Li2.CrO4 & $s$ & $14307-35-8$ & NA & 129.9 \\
\hline Lithium Hydroxide & $\mathrm{Li} . \mathrm{OH}$ & $s$ & $1310-65-2$ & NA & 24.0 \\
\hline Mercury Vapor (as $\mathrm{Hg}$ ) & $\mathrm{Hg}$ & $G$ & $7439-97-6$ & 0.0012 & 200.6 \\
\hline Methane & $\mathrm{CH} 4$ & $G$ & $74-82-8$ & 760 & 16.0 \\
\hline Methanol & $\mathrm{CH} 3 . \mathrm{OH}$ & $L$ & $67-56-1$ & 100 & 32.0 \\
\hline Methyl Chloride (Ca) & $\mathrm{CH} 3 . \mathrm{CI}$ & G & $74-87-3$ & 760 & 50.5 \\
\hline Methyl Fluoride (as Fluoride) & $\mathrm{CH} 3 . \mathrm{F}$ & $G$ & $593-53-3$ & 760 & 34.0 \\
\hline Methyl Iodide (Ca) & $\mathrm{CH} 3.1$ & $L$ & $74-88-4$ & 400 & 142.0 \\
\hline Methyl Mercaptan & $\mathrm{CH} 3 . \mathrm{SH}$ & G & $74-93-1$ & 760 & 48.1 \\
\hline Monomethylamine & CH3.NH2 & G & $74-89-5$ & 760 & 31.1 \\
\hline Monomethylhydrazine (Ca) & CH3.NH.NH2 & $L$ & $60-34-4$ & 50 & 46.1 \\
\hline NickelCarbonyl (asNi) (Ca) & $\mathrm{Ni} .(\mathrm{CO}) 4$ & $L$ & $13463-39-3$ & 315 & 170.7 \\
\hline Nitric Acid & HNO3 & $L$ & $7697-37-2$ & 48 & 63.0 \\
\hline Nitrogen Dioxide & $\mathrm{NO2}$ & $G$ & $10102-44-0$ & 760 & 46.0 \\
\hline Nitrous Oxide & $\mathrm{N} 2.0$ & $G$ & $10024-97-2$ & 760 & 44.0 \\
\hline Ozone & 03 & G & $10028-15-6$ & 760 & 48.0 \\
\hline Perchloroethyene & $\mathrm{cl} 2 \mathrm{C}=\mathrm{ccl} 2$ & $L$ & $127-18-4$ & 14 & 165.8 \\
\hline Perfuoroisobutylene & $(\mathrm{CF} 3) 2 . \mathrm{C}=\mathrm{CF} 2$ & $G$ & $382-21-8$ & 760 & 200.0 \\
\hline Phenol & C6.H5.OH & $s$ & $108-95-2$ & 0.4 & 94.1 \\
\hline Phosgene & $\mathrm{CO} . \mathrm{Cl2}$ & $G>8.2 C$ & $75-44-5$ & 760 & 98.9 \\
\hline Phosphine & $\mathrm{PH3}$ & $G$ & $7803-51-2$ & 760 & 34.0 \\
\hline Phosphoric Acid & H3.PO4 & $L / S$ & $7664-38-2$ & 0.03 & 98.0 \\
\hline
\end{tabular}




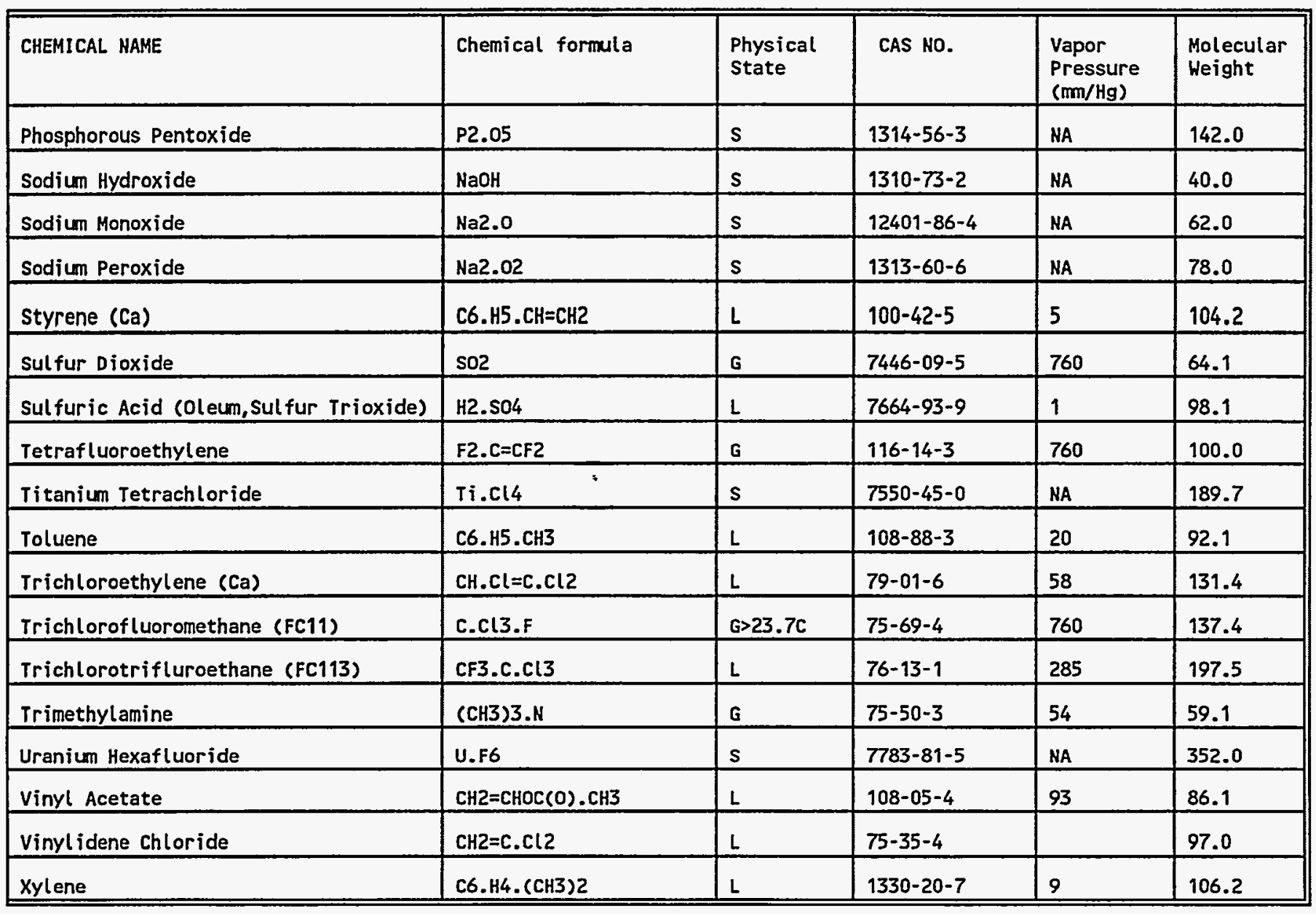


Table 2

\section{Chemical Limits Based on ERPG or Hierarchy-based A7ternative Concentrations}

\begin{tabular}{|c|c|c|c|c|}
\hline CHEMICAL NAME & PEL-TWA $\left(\mathrm{mg} / \mathrm{M}^{3}\right)$ & ERPG-1 $\left(\mathrm{mg} / \mathrm{M}^{3}\right)$ & ERPG-2 $\left(\mathrm{mg} / \mathrm{m}^{3}\right)$ & ERPG $-3\left(\mathrm{mg} / \mathrm{M}^{3}\right)$ \\
\hline Acetone & 1815 & 2420 & 20570 & 48400 \\
\hline Acrolein & 0.233 & 0.233 & 1.165 & 6.99 \\
\hline Acrylic Acid & 5.897 & 5.897 & 147.4 & 2211.7 \\
\hline Acrylonitrile (Ca) & 4.42 & 22.1 & .110 .5 & 1105 \\
\hline Allyl Chloride & 3.18 & 9.54 & 127.2 & 954 \\
\hline Aluminum Oxide & 10 & 15 & 15 & 25 \\
\hline Ammonia & 17.75 & 17.75 & 142 & 710 \\
\hline Arsenic (Inorganic) as As (Ca) & 0.01 & 0.6 & 1.4 & 100 \\
\hline Arsenic (Organic compounds) as As & 0.2 & 0.2 & & \\
\hline Arsine (Ca) & 0.162 & 3.24 & 3.24 & 16.2 \\
\hline Benzene(Ca) & 3.25 & 16.25 & 162.5 & 9750 \\
\hline Beryll ium (Ca) & 0.002 & 0.006 & 25 & 100 \\
\hline Bromine & 0.664 & 1.328 & 6.64 & 33.2 \\
\hline Bromotrifluoromethane & 6090 & & 152249 & 243599 \\
\hline 1,3 -Butadiene (Ca) & 22.5 & 22.5 & 112.5 & 11250 \\
\hline Carbon Disulfide & 3.16 & 3.16 & 158 & 1580 \\
\hline Carbon Monoxide & 40.6 & 464 & 464 & 870 \\
\hline Carbon Tetrachloride (Ca) & 12.78 & 127.8 & 639 & 4792 \\
\hline Chlorine & 1.475 & 2.95 & 8.85 & 59 \\
\hline Chlorine Triftuoride & & 0.385 & 3.85 & 38.5 \\
\hline Chloroacetyl Chloride & 0.231 & 0.462 & 4.62 & 46.2 \\
\hline Chloroform (Ca) & 9.92 & 148.8 & 496 & 4960 \\
\hline Chloropicrin & 0.683 & 1.366 & 1.366 & 20.49 \\
\hline Chlorosulfonic Acid & & 2 & 10 & 30 \\
\hline Chlorotrifluoroethylene & & 95.3 & 476.5 & 1429 \\
\hline Crotonaldehyde (Ca) & 5.92 & 5.92 & 29.1 & 145.5 \\
\hline Dichlorodifluoromethane (FC12) & 5030 & 15090 & 50300 & 251500 \\
\hline Dichlorofluoromethane (FC21) & 42.8 & 128.4 & 428 & 214000 \\
\hline Dichlorotetrafluoroethane (FC114) & 6990 & 20969 & 69900 & 349489 \\
\hline Diketene & & 3.44 & 17.2 & 172 \\
\hline Dimethylamine & 1.87 & 1.87 & 187 & 935 \\
\hline Dimethylformamide & 15.2 & 15.2 & 30.4 & 304 \\
\hline
\end{tabular}




\begin{tabular}{|c|c|c|c|c|}
\hline CHEMICAL NAME & PEL-THA $\left(\mathrm{mg} / \mathrm{m}^{3}\right)$ & ERPG- $1\left(\mathrm{mg} / \mathrm{M}^{3}\right)$ & ERPG-2 $\left(\mathrm{mg} / \mathrm{M}^{3}\right)$ & ERPG-3 $\left(\mathrm{mg} / \mathrm{m}^{3}\right)$ \\
\hline 1,1-Dimethylhydrazine (Ca) & 1.25 & 3.75 & 12.5 & 125 \\
\hline Epichlorohydrin (Ca) & 7.7 & 7.7 & 77 & 385 \\
\hline Ethanolamine & 7.62 & 15.24 & 127 & 2540 \\
\hline Ethylene Glycol & 10.16 & & 101.6 & 152.4 \\
\hline Ethylene Oxide (Ca) & 1.83 & 5.49 & 91.5 & 915 \\
\hline Fluorine & 0.158 & 3.16 & 11.85 & 15.8 \\
\hline Formaldehyde (Ca) & 1.23 & 1.23 & 12.26 & 30.7 \\
\hline Hexachlorobutadiene & 0.213 & 32 & 106.6 & 320 \\
\hline Hydrazine (Ca) & 0.133 & 0.399 & 1.06 & 13.3 \\
\hline Hydrogen Chloride & 0.76 & 4.56 & 30.4 & 152 \\
\hline Hydrogen Fluoride & 2.49 & 4.15 & 16.6 & 41.5 \\
\hline Hydrogen Peroxide $(30 \%)$ & 1.41 & 4.23 & 35.25 & 70.5 \\
\hline Hydrogen Sulfide & 14.2 & 14.2 & 42.6 & 142 \\
\hline Isobutyronitrile & & 28.26 & 141.3 & 565.2 \\
\hline Isopropyl Alcohol & 1000 & 1000 & 1000 & 30000 \\
\hline Lithium Bromide & 1 & & 15 & \\
\hline Lithium Chromate & & & 0.1 & \\
\hline Lithium Hydroxide & 0.025 & 0.05 & 0.1 & 0.5 \\
\hline Mercury Vapor (as $\mathrm{Hg}$ ) & 0.05 & 0.15 & 0.2 & 28 \\
\hline Methane & 3272 & & 3272 & \\
\hline Methanol & 261.8 & 261.8 & 1308.8 & 6544 \\
\hline Methyl Chloride (Ca) & 105 & 210 & 840 & 2100 \\
\hline Methyl Fluoride (as Fluoride) & 2.5 & 7.5 & 12.5 & \\
\hline Methyl lodide (Ca) & 11.8 & 147.5 & 295 & 737.5 \\
\hline Methyl Mercaptan & 1 & 1 & 50 & 200 \\
\hline Monomethylamine & 12.7 & 12.7 & 127 & 636 \\
\hline Monomethylhydrazine (Ca) & 0.452 & & 0.94 & 94.3 \\
\hline NickelCarbonyl (asNi) (Ca) & 0.0071 & 0.355 & 0.355 & 49.7 \\
\hline Nitric Acid & 5.24 & 5.24 & 39.3 & 78.6 \\
\hline Nitrogen Dioxide & 3.82 & 3.82 & 28.6 & 57.3 \\
\hline Nitrous Oxide & 90 & 270 & 17996 & 35992 \\
\hline Ozone & 0.2 & 0.6 & 2 & 20 \\
\hline Perchloroethyene & 169.5 & 678 & 1356 & 3391 \\
\hline Perfuoroisobutylene & & & 0.818 & 2.45 \\
\hline Phenol & 19.2 & 38.5 & 192.4 & 769.7 \\
\hline Phosgene & 0.41 & 0.82 & 0.82 & 4.1 \\
\hline Phosphine & 0.42 & 1.14 & 70.5 & 141 \\
\hline
\end{tabular}




\begin{tabular}{|c|c|c|c|c|}
\hline CHEMICAL NAME & PEL-TWA $\left(\mathrm{mg} / \mathrm{M}^{3}\right)$ & ERPG-1 (mg/ $\left.\mathrm{M}^{3}\right)$ & ERPG-2 $\left(\mathrm{mg} / \mathrm{M}^{3}\right)$ & ERPG-3 $\left(\mathrm{mg} / \mathrm{M}^{3}\right)$ \\
\hline Phosphoric Acid & 1 & 3 & 5 & 10000 \\
\hline Phosphorous Pentoxide & & 5 & 25 & 100 \\
\hline Sodium Hydroxide & & 2 & 40 & 100 \\
\hline \multicolumn{5}{|l|}{ Sodium Monoxide } \\
\hline \multicolumn{5}{|l|}{ Sodium Peroxide } \\
\hline Styrene (Ca) & 216.5 & 433 & 866 & 3464 \\
\hline Sulfur Dioxide & 0.80 & 0.80 & 8 & 40 \\
\hline Sulfuric Acid (oleum, Sulfur Trioxide) & 1 & 2 & 10 & 30 \\
\hline Tetrafluoroethylene & & 818 & 4090 & 40900 \\
\hline Titanium Tetrachloride & & 5 & 20 & 100 \\
\hline Toluene & 383 & 574.5 & 1149 & 7660 \\
\hline Trichloroethylene (Ca) & 273 & 546 & 2730 & 5460 \\
\hline Irichlorofluoromethane (FC11) & 562 & & 8429 & 56196 \\
\hline Trichlorotrifluroethane (FC113) & 7790 & 9738 & 11685 & 35055 \\
\hline Trimethylamine & 24.2 & 24.2 & 242 & 1209 \\
\hline Uranium Hexafluoride & 2.88 & 14.4 & 144 & 288 \\
\hline Vinyl Acetate & 17.6 & 17.6 & 264 & 1761 \\
\hline Vinylidene Chloride & 3.97 & 39.7 & 39.7 & \\
\hline Xylene & 441 & 661.5 & 882 & 4410 \\
\hline
\end{tabular}

All units are $\mathrm{mg} / \mathrm{M}^{3}$

Values were converted from PPM by the relationship: $m g / M^{3}=P P M * M W / 24.45$ 
Tie Line

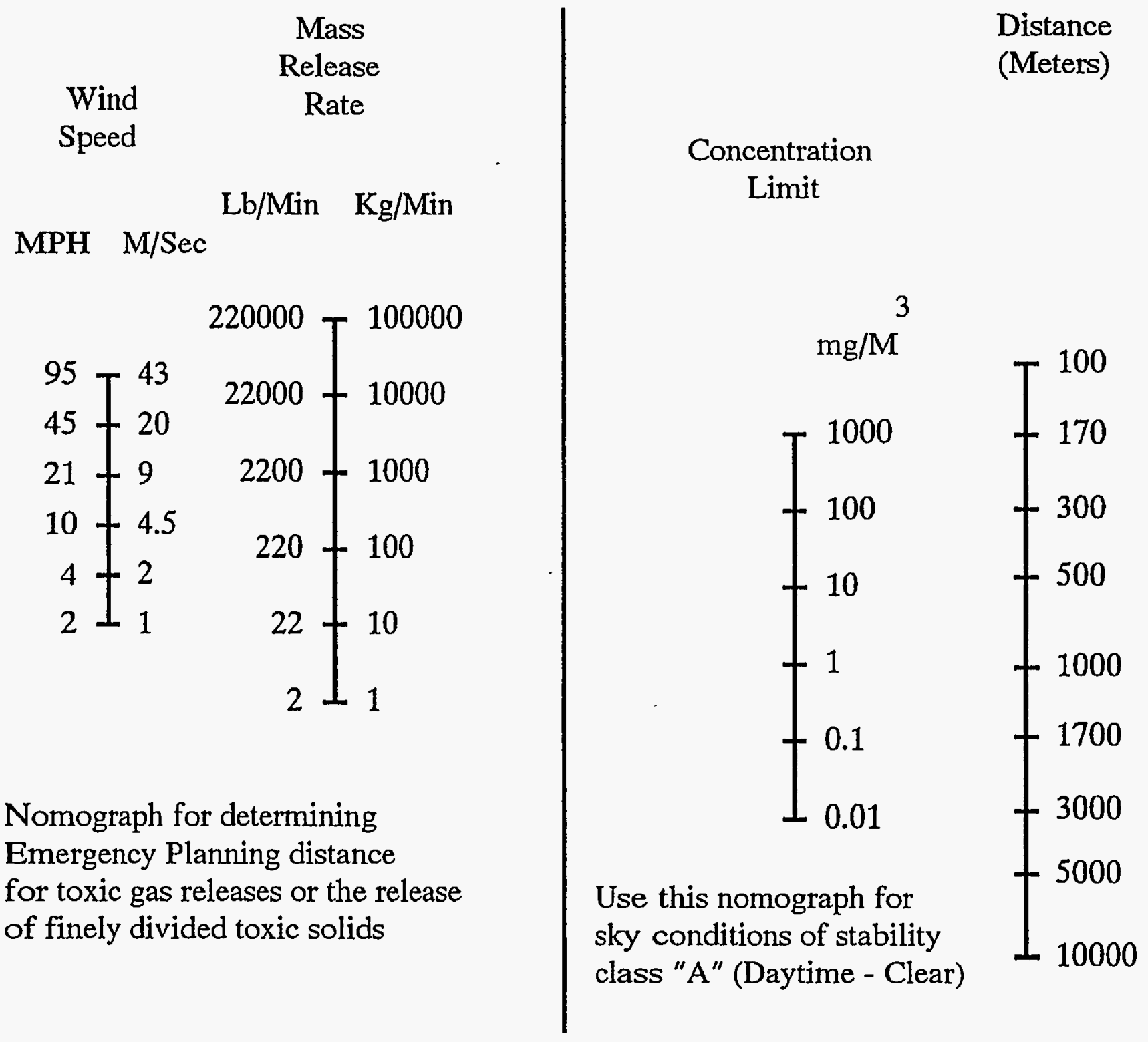

Figure 1 
Tie Line

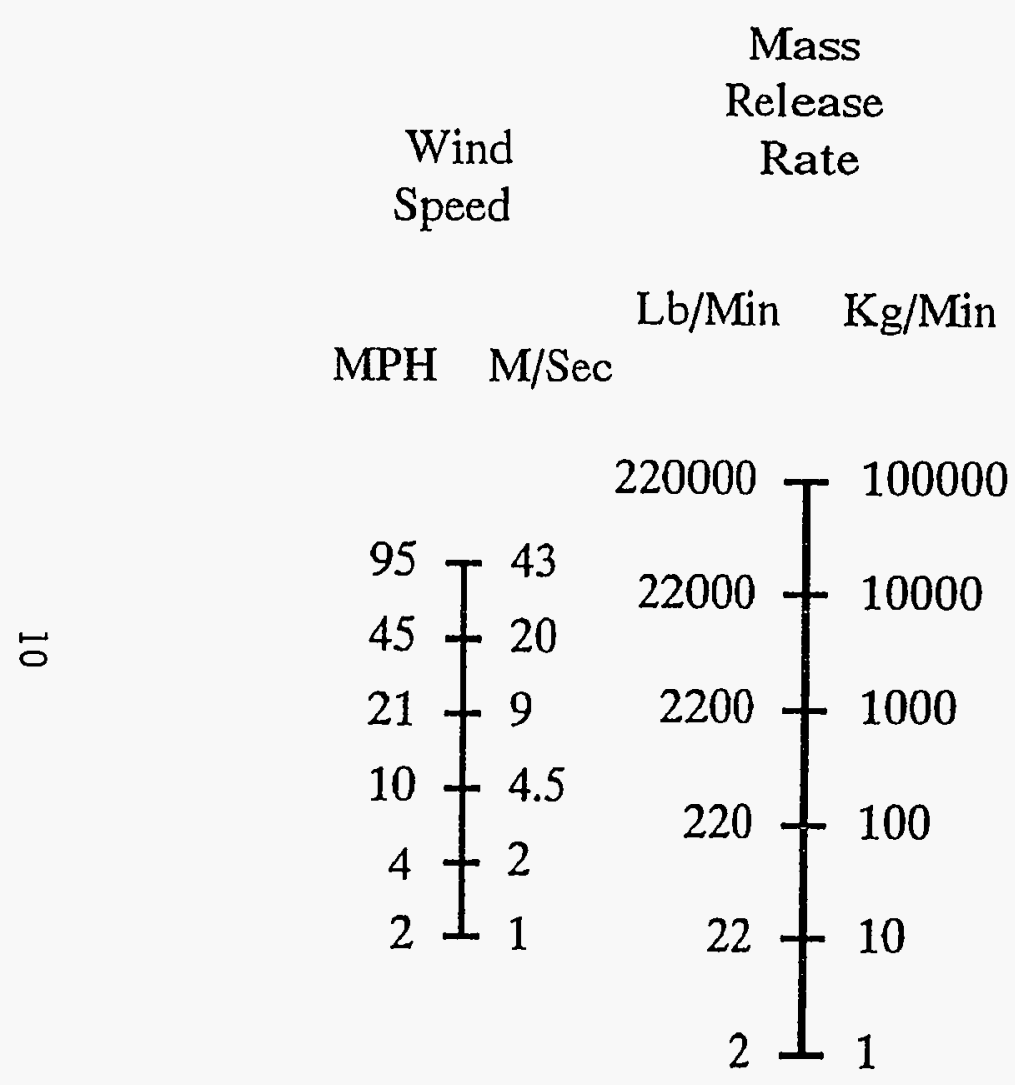

Nomograph for determining

Emergency Planning distance for toxic gas releases or the release of finely divided toxic solids

Distance

(Meters)

\section{Concentration}

Limit

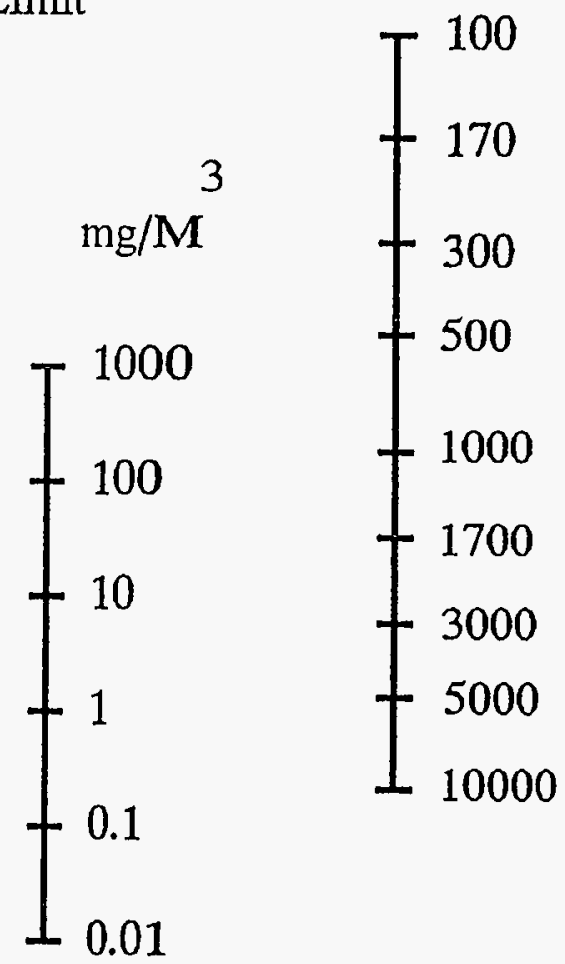

Use this nomograph for sky conditions of stability class " $D$ " (Day or Night Cloudy) 


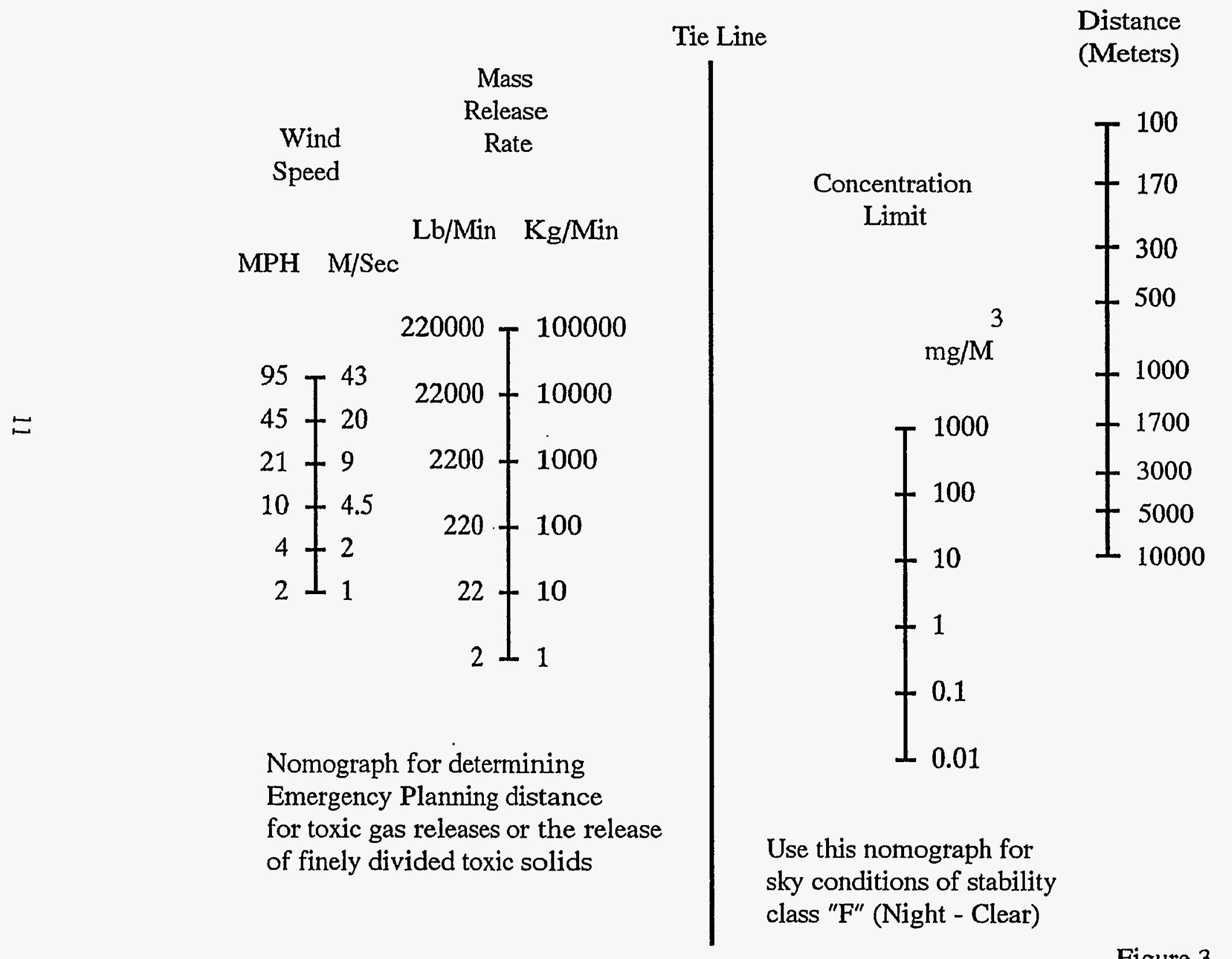

Figure 3 


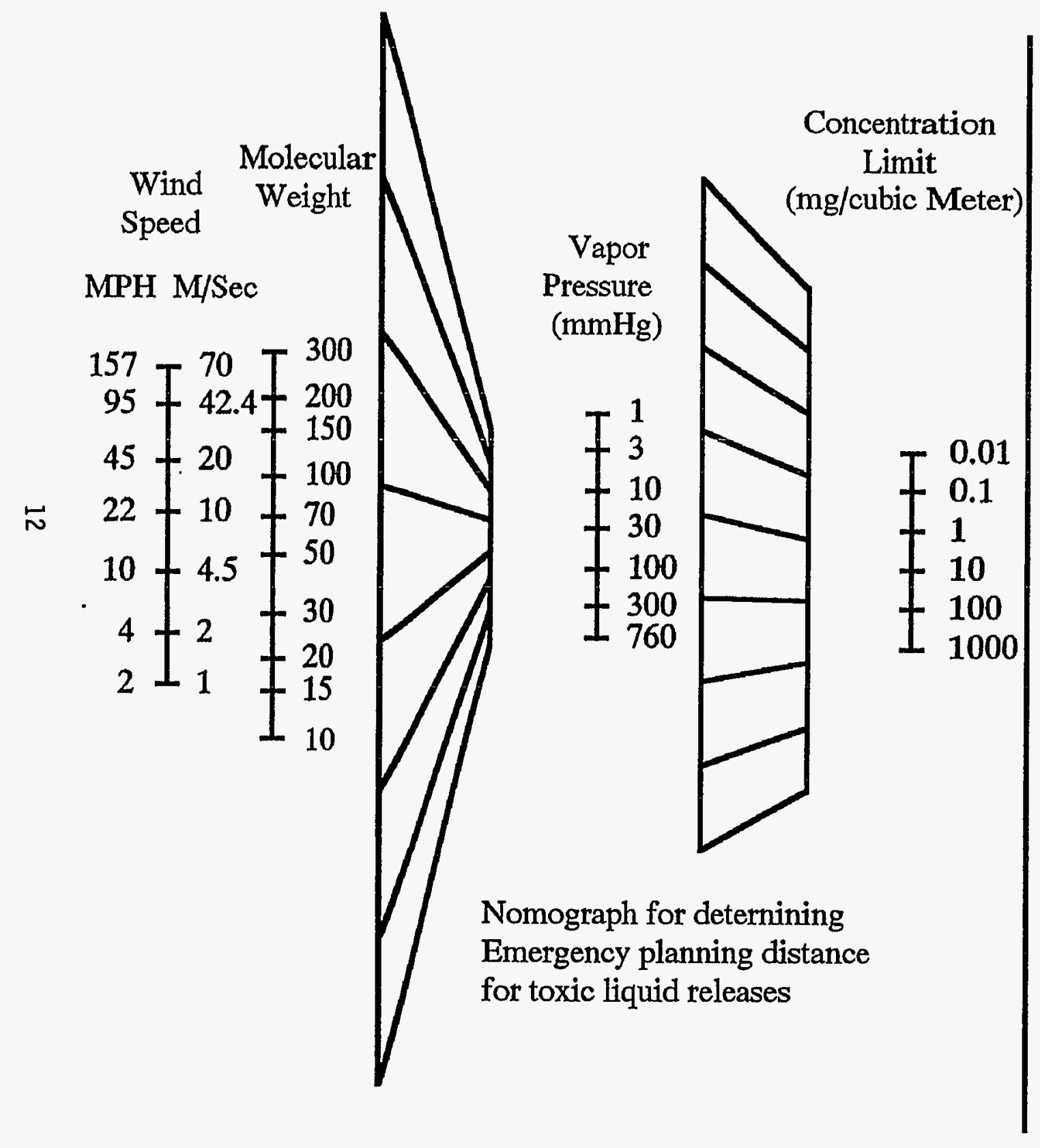

Distance

(Meters)

Area of

Spill

Sq Ft Sq M

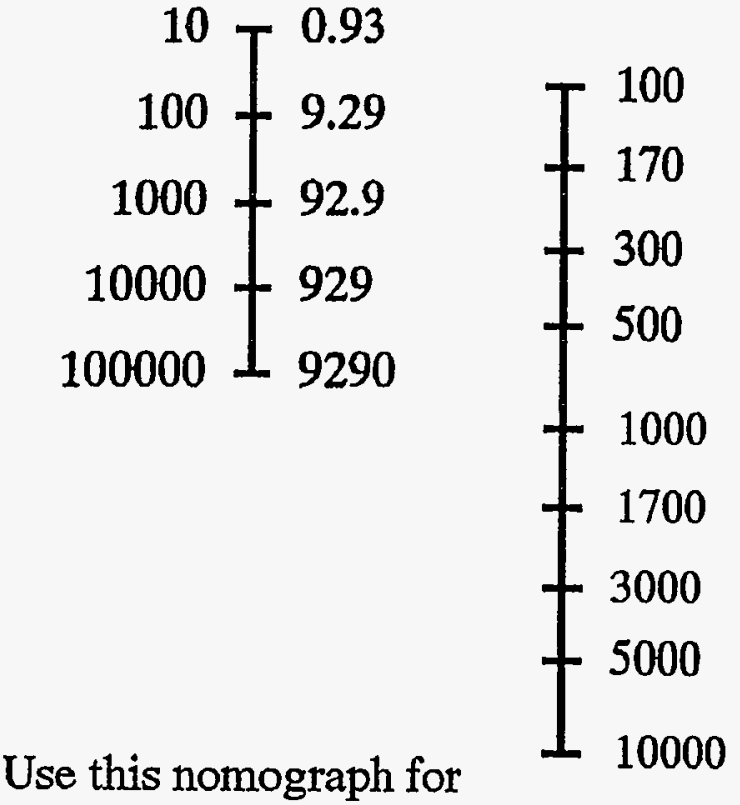

sky conditions of stability class "A" (Daytime - Clear)

Figure 4 

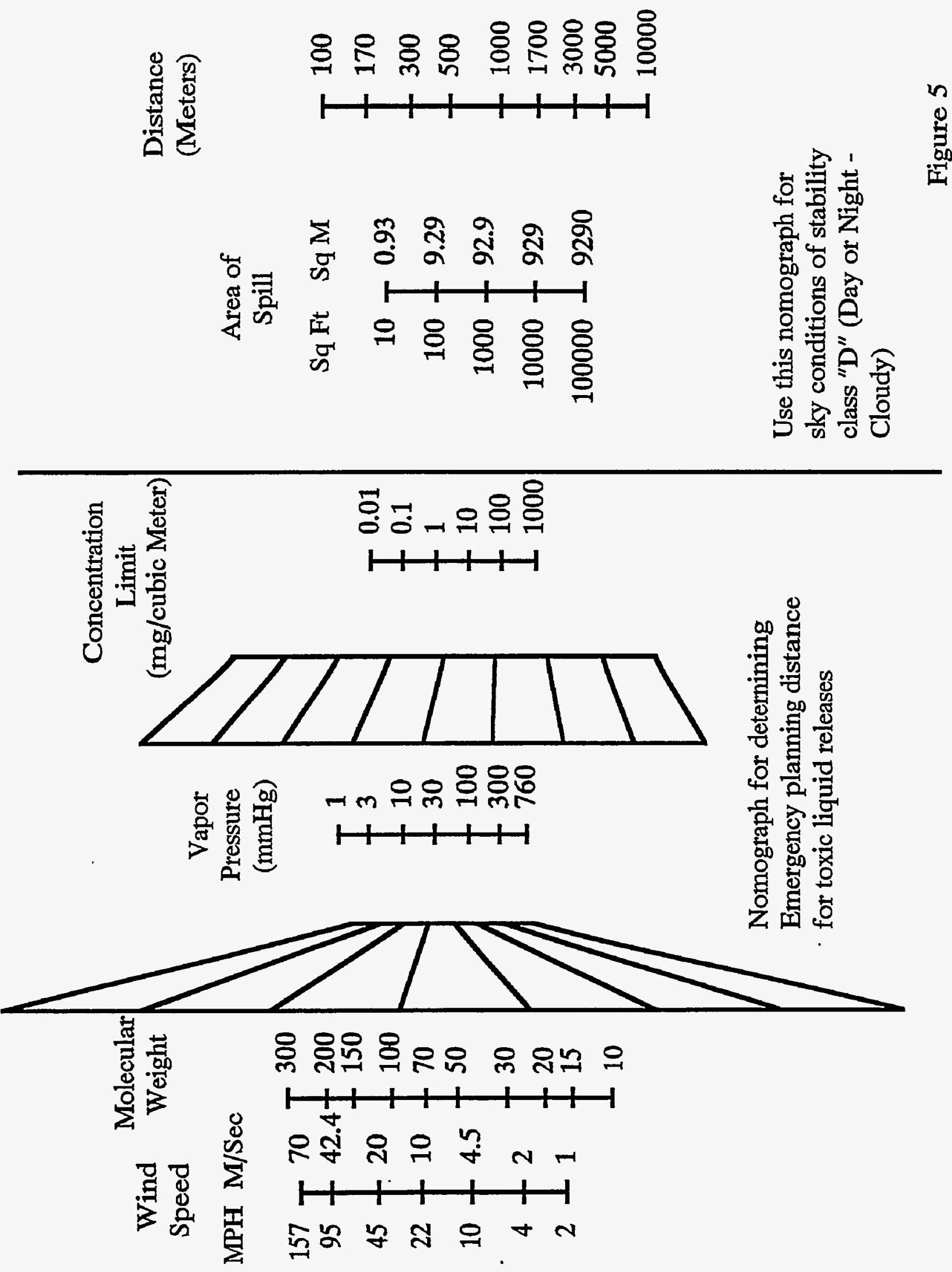


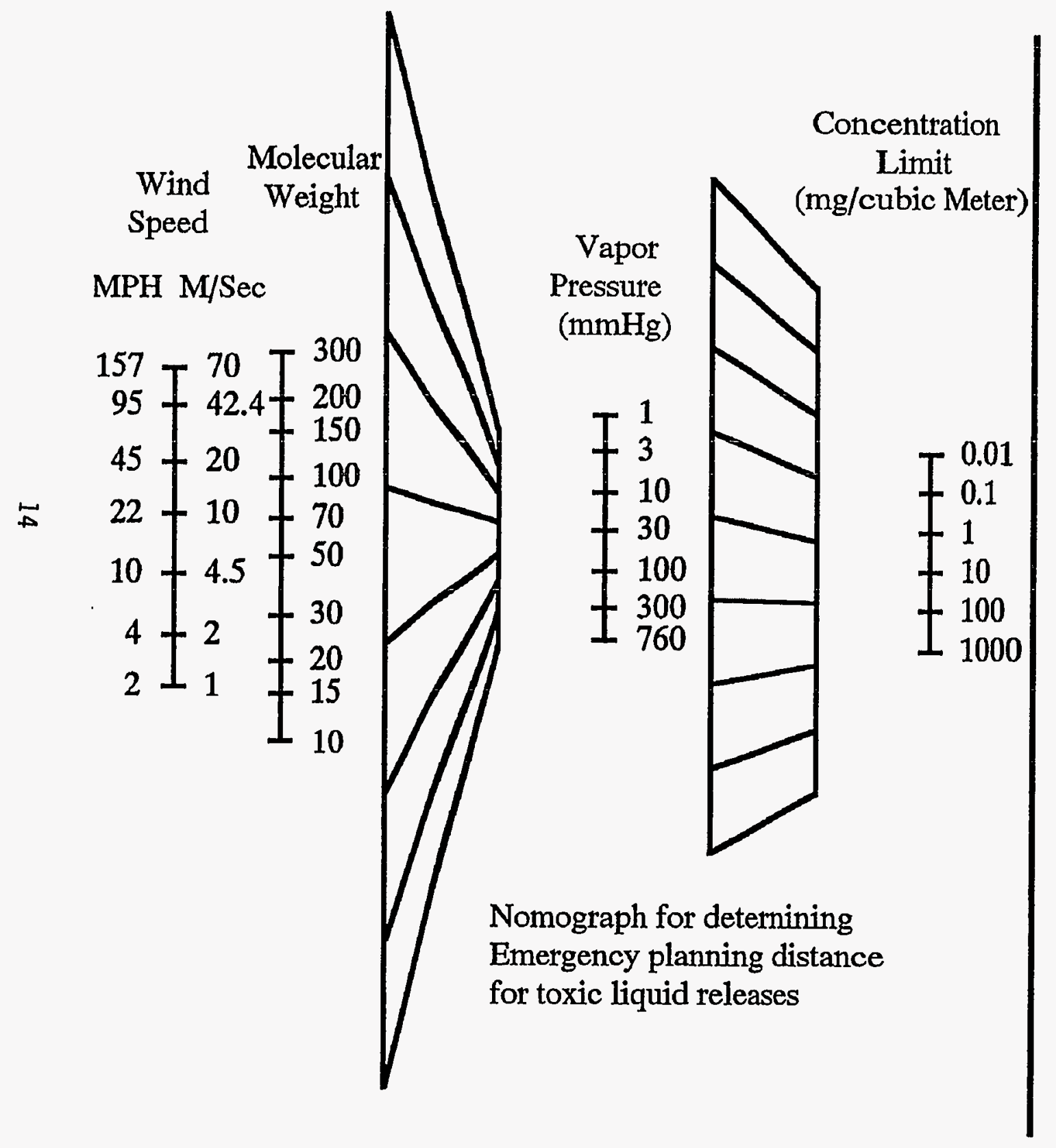

Use this nomograph for sky conditions of stability class "F" (Night - Clear) 
Table 3 Widths of plume for each class of stability as a function of distance from source

\begin{tabular}{|c|c|c|c|}
\hline Distance (M) & "A" Width (M) & "D" Width (M) & "F" Width (M) \\
\hline 100 & 43.78 & 15.92 & 7.96 \\
\hline 200 & 87.13 & 31.68 & 15.84 \\
\hline 300 & 130.1 & 47.30 & 23.65 \\
\hline 400 & 172.6 & 62.76 & 31.38 \\
\hline 500 & 214.7 & 78.07 & 39.04 \\
\hline 600 & 256.4 & 93.24 & 46.62 \\
\hline 700 & 297.8 & 108.3 & 54.14 \\
\hline 800 & 338.7 & 123.2 & 61.58 \\
\hline 900 & 379.3 & 137.9 & 68.96 \\
\hline 1000 & 419.5 & 152.6 & 76.28 \\
\hline 2000 & 803.3 & 292.1 & 146.1 \\
\hline 3000 & 1158 & 421.0 & 210.5 \\
\hline 4000 & 1487 & 540.9 & 270.4 \\
\hline 5000 & 1796 & 653.2 & 326.6 \\
\hline 6000 & 2087 & 758.9 & 379.5 \\
\hline 7000 & 2362 & 859.0 & 429.5 \\
\hline 8000 & 2624 & 954.1 & 477.0 \\
\hline 9000 & 2873 & 1045 & 522.3 \\
\hline 10000 & 3111 & 1131 & 565.7 \\
\hline
\end{tabular}

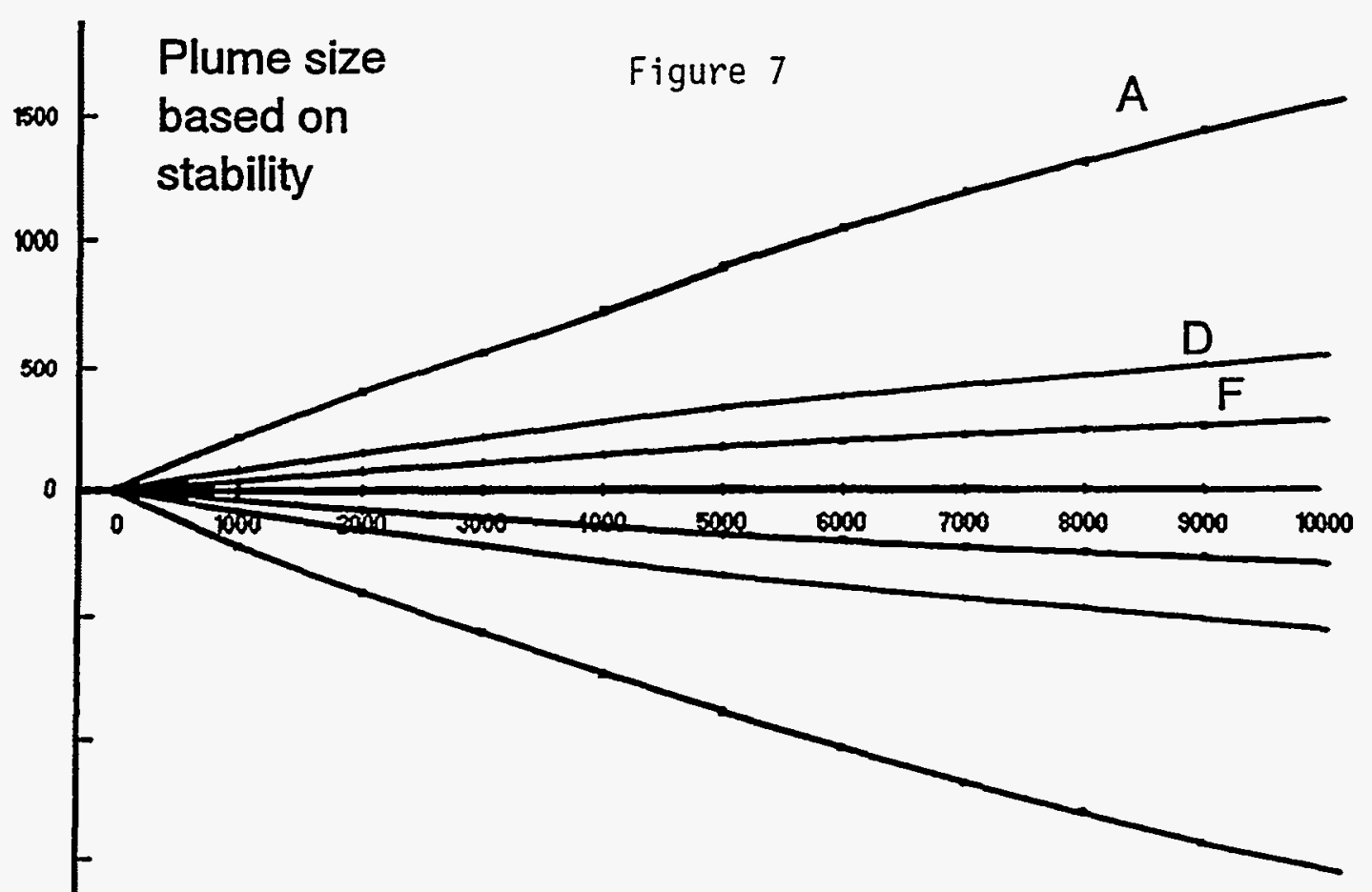




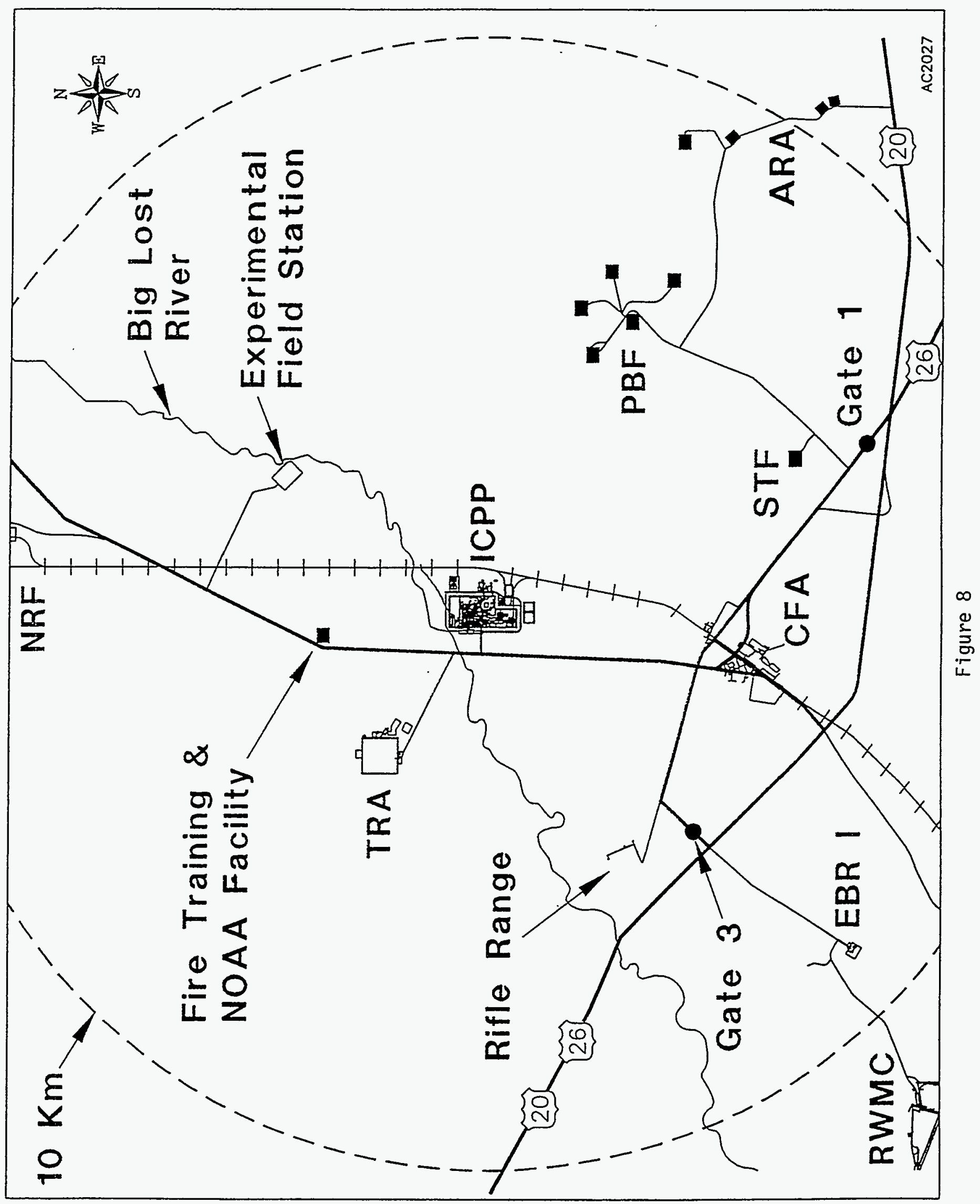




\section{Appendix A \\ Listing and Analysis of Limit Parameters Found for 88 Chemicals}


-.......... -

- ........

-

. 
The selection of chemicals and their concentration limits were based on the results of guidelines established by the Westinghouse M\&O Subcommittee on Nonradiological risk (WSRC 1993). The material that follows is edited from their report.

The chemicals 1isted in Table A-1 include al1 those for which ERPG values have been published to date, all additional chemicals for which the Committee on Toxicology of the National Research Council, National Academy of Sciences, has developed EEGLs, SPEGLs, and CEGLs for the US military, and all chemicals for which ERPG values are either in the process of being developed, or which have been identified, by a subcommittee of DOE's Emergency Management Advisory Committee, as having a high priority for ERPG-value development.

A11 concentrations found for a11 88 chemicals for the fifteen concentration Timit parameters in Appendix $C$ were compared. In making these comparisons, it must be clearly understood that each limit parameter was developed for a different purpose, addressing different populations, different time periods, and different toxicologic endpoints. At times the organizations responsible for development of chemical-specific values derived values that had nothing to do with toxicity and/or available data. For example, about $12 \%$ of IDLH values are based upon the chemical's lower explosive limit, since no evidence could be found to the effect that exposure to the chemical concerned was "immediately dangerous to life and health" at lower concentrations.

Ratios of individual pairs of values were calculated along with their mean, standard deviation, and standard deviation as a percentage of their mean. This was done, first, for all the pairs found $(N=$ total number of pairs of parameters available for comparison), and then excluding a few ratios judged to be outliers ( $n=$ number of ratios used for the statistics). This judgement was made on the basis of large deviations of particular ratios from the mean value for a particular comparison. The results of these comparisons were used to develop the hierarchy of recommended alternative guidelines presented in Table 2. The various alternative guidelines are plotted against the primary guidelines. These recommendations differ somewhat from those already in use (see Tables 1 and 2). For example, the mean ratio of ERPG-2 to IDLH vaTues is $0.26 \pm 169 \%$ for $n=N=34$, whereas the mean ratio of ERPG-3 to IDLH values is $1.04 \pm 174 \%$ for $n=N=34$ and $0.79 \pm 112 \%$ for $n=32$ (i.e., $n<N$ ). The comparison between IDLH and ERPG-3 values is clearly much better, which is to be expected since both these parameters are associated with Tife-threatening effects. Another difference concerns the use of SPEGL (60 min) values.

D.0.E.'s Emergency Management Guide (Guidance for Hazard Assessment, 6-26-92) recommends use of the 1-hour SPEGL value in place of ERPG-2 (p. 37). However, SPEGLs were developed for only 5 chemicals: 3 hydrazine compounds, hydrogen chloride, and nitrogen dioxide. In every case, the SPEGL value compares better with the PEL-TWA or TLV-TWA (see below). Of these, only hydrogen chloride has EEGL and CEGL values.

The M\&O subcommittee initially considered recommending the use of PEL-STEL or TLV-STEL values as the primary guidelines instead of ERPG-1 values, since the latter are not based exclusively on toxicologic considerations. Some ERPG-1 values are based on odor or perception threshold concentrations. In some instances, the ERPG-1 value would be equal to or greater than the ERPG-2 value, i.e., severe or irreversible health effects could occur at concentrations lower than those at which the chemicals would be perceived. For these chemicals, no ERPG-1 value has been developed. For some other 
particularly odiferous chemicals (e.g., the amines and sulfides), the ratio of ERPG-2 to ERPG-1 values is 7 arge. In addition, there are 4 chemicals (1,3-butadiene, hydrogen sulfide, methyl mercaptan and trimethylamine) for which the ERPG-1 value is one-hundredth of the PEL-TWA value, which is the permissible exposure limit for an 8-hour workday, 5 days a week. However, the M\&O subcommittee recommended use of ERPG-1 values as primary guidelines for consistency, but a1so recommended that short-term exposure limit values (the more conservative of PEL-ST and TLV-STEL) be used for particularly odiferous chemicals. These chemicals include carbon disulfide, hydrogen sulfide, sulfur dioxide, and trimethylamine. Methyl mercaptan lacks short-term exposure limits, so the remaining hierarchy parameter (TLV-TWA $\times 3$ ) was used in place of ERPG-1.

For reasons already explained, the M\&O subcommittee did not, in general, consider it appropriate to use fixed fractions or fixed multiples of parameters that have been developed with specific toxicologic endpoints in mind. It is for this reason that they did not used IDLH $\times 0.5$, even though the values compare quite well with ERPG-3s. However, an exception has been made for chemicals that do not have short-term exposure limit or ceiling values, in which case they are included in the alternative parameter hierarchy, TLV-TWA $x$ 3 for ERPG-1 and TLV-TWA $\times 5$ for ERPG-2. The justification for this recommendation is contained in the ACGIH 1991-1992 Threshold Limit Value booklet.

60-minute SPEGL values, which are not Tisted in Table A-1, are given below (NAS 1985):

Hydrazine $0.12 \mathrm{ppm}$ Hydrogen Chloride 1 ppm Monomethylhydrazine 
Table A-1

Chemical-Specific Primary or Hierarchy-based Alternative Concentrations (based on October 1992 limits)

\begin{tabular}{|c|c|c|c|c|c|}
\hline CHEMICAL NAME & PEL-TWA & ERPG-1 & ERPG-2 & ERPG-3 & UNITS \\
\hline Acetone & 750 & 1000 & 8500 & 20000 & $\mathrm{ppm}$ \\
\hline Acrolein & 0.1 & 0.1 & 0.5 & 3 & ppm \\
\hline Acrylic Acid & $2^{*}$ & 2 & 50 & 750 & ppm \\
\hline Acrylonitrile (Ca) & 2 & 10 & 50 & 500 & ppm \\
\hline Allyl Chloride & 1 & 3 & 40 & 300 & $\mathrm{ppm}$ \\
\hline Aluminum Oxide & 10 & $15^{*}$ & $15^{*}$ & 25 & $\mathrm{mg} / \mathrm{m} 3$ \\
\hline Ammonia & 25 & 25 & 200 & 1000 & $\mathrm{ppm}$ \\
\hline Arsenic (Inorganic) as As (Ca) & 0.01 & 0.6 & 1.4 & 100 & $\mathrm{mg} / \mathrm{m} 3$ \\
\hline $\begin{array}{l}\text { Arsenic (Organic compounds) } \\
\text { as As }\end{array}$ & $0.2^{*}$ & 0.2 & & & $\mathrm{mg} / \mathrm{m} 3$ \\
\hline Arsine (Ca) & 0.05 & $1^{*}$ & (1) & (5) & $\mathrm{ppm}$ \\
\hline Benzene (Ca) & 1 & 5 & 50 & 3000 & ppm \\
\hline Beryllium (Ca) & 0.002 & 0.006 & (25) & (100) & $\mathrm{mg} / \mathrm{m} 3$ \\
\hline Bromine & 0.1 & 0.2 & 1 & 5 & $\mathrm{ppm}$ \\
\hline Bromotrifluoromethane & 1000 & & 25000 & 40000 & $\overline{\mathrm{ppm}}$ \\
\hline 1,3-Butadiene (Ca) & $10^{*}$ & 10 & 50 & 5000 & ppm \\
\hline Carbon Disulfide & $1^{*}$ & 1 & 50 & 500 & ppm \\
\hline Carbon Monoxide & 35 & 400 & 400 & 750 & $\mathrm{ppm}$ \\
\hline Carbon Tetrachloride(Ca) & 2 & 20 & 100 & 750 & ppm \\
\hline Chlorine & 0.5 & 1 & 3 & 20 & ppm \\
\hline Chlorine Trifluoride & & 0.1 & 1 & 10 & ppm \\
\hline Chloroacetyl Chloride & 0.05 & 0.1 & 1 & 10 & ppm \\
\hline Chloroform (Ca) & 2 & 30 & 100 & 1000 & ppm \\
\hline Chloropicrin & 0.1 & $0.2^{*}$ & 0.2 & 3 & $\mathrm{ppm}$ \\
\hline Chlorosulfonic Acid & & 2 & 10 & 30 & $\mathrm{mg} / \mathrm{m} 3$ \\
\hline Chlorotrifluoroethylene & & 20 & 100 & 300 & $\mathrm{ppm}$ \\
\hline Crotonaldehyde (Ca) & 2 & 2 & 10 & 50 & ppm \\
\hline $\begin{array}{l}\text { Dichlorodifluoromethane } \\
\text { (FC12) }\end{array}$ & 1000 & 3000 & 10000 & 50000 & $\mathrm{ppm}$ \\
\hline Dichlorofluoromethane (FC21) & 10 & 30 & 100 & 50000 & ppm \\
\hline $\begin{array}{l}\text { Dichlorotetrafluoroethane } \\
\text { (FC114) }\end{array}$ & 1000 & 3000 & 10000 & 50000 & ppm \\
\hline Diketene & & 1 & 5 & 50 & $\mathrm{ppm}$ \\
\hline Dimethylamine & $1^{*}$ & 1 & 100 & 500 & $\mathrm{ppm}$ \\
\hline Dimethylformamide & $5^{*}$ & (5) & (10) & $(100)$ & ppm \\
\hline 1,1-Dimethylhydrazine (Ca) & 0.5 & 1.5 & 5 & 50 & $\mathrm{ppm}$ \\
\hline Epichlorohydrin (Ca) & 2 & 2 & 20 & 100 & $\mathrm{ppm}$ \\
\hline Ethanolamine & 3 & 6 & 50 & 1000 & $\mathrm{ppm}$ \\
\hline Ethylene Glycol & 4 & & 40 & 60 & $\mathrm{ppm}$ \\
\hline Ethylene Oxide (Ca) & 1 & $\overline{3}$ & 50 & 500 & ppm \\
\hline Fluorine & 0.1 & 2 & 7.5 & 10 & $\mathrm{ppm}$ \\
\hline
\end{tabular}




\begin{tabular}{|c|c|c|c|c|c|}
\hline CHEMICAL NAME & PEL-TWA & ERPG-1 & ERPG-2 & ERPG-3 & UNITS \\
\hline Formaldehyde (Ca) & 1 & 1 & 10 & 25 & $\mathrm{ppm}$ \\
\hline Hexachlorobutadiene & 0.02 & $\overline{3}$ & 10 & 30 & $\mathrm{ppm}$ \\
\hline Hydrazine (Ca) & 0.1 & 0.3 & $(0.8)$ & (10) & $\mathrm{ppm}$ \\
\hline Hydrogen Chloride & 0.5 & 3 & 20 & 100 & ppm \\
\hline Hydrogen Fluoride & 3 & 5 & 20 & 50 & $\mathrm{ppm}$ \\
\hline Hydrogen Peroxide(30\%) & 1 & 3 & (25) & (50) & $\mathrm{ppm}$ \\
\hline Hydrogen Sulfide & 10 & $10^{* *}$ & 30 & 100 & ppm \\
\hline Isobutyronitrile & & 10 & 50 & 200 & $\mathrm{ppm}$ \\
\hline Isopropyl Alcohol & 400 & $400^{*}$ & 400 & 12000 & $\mathrm{ppm}$ \\
\hline Lithium Bromide & 1 & & 15 & & $\mathrm{mg} / \mathrm{m} 3$ \\
\hline Lithium Chromate & & & 0.1 & & $\mathrm{mg} / \mathrm{m} 3$ \\
\hline Lithium Hydroxide /Hydride & 0.025 & 0.05 & 0.1 & 0.5 & $\mathrm{mg} / \mathrm{m3}$ \\
\hline Mercury Vapor (as $\mathrm{Hg}$ ) & 0.05 & 0.15 & 0.2 & 28 & $\mathrm{mg} / \mathrm{m} 3$ \\
\hline Methane & 5000 & & 5000 & & $\mathrm{ppm}$ \\
\hline Methanol & 200 & 200 & 1000 & 5000 & $\mathrm{ppm}$ \\
\hline Methyl Chloride (Ca) & 50 & 100 & 400 & 1000 & $\mathrm{ppm}$ \\
\hline Methyl Fluoride (as fluoride) & 2.5 & 7.5 & 12.5 & & $\mathrm{mg} / \mathrm{m} 3$ \\
\hline Methyl lodide (Ca) & 2 & 25 & 50 & 125 & $\mathrm{ppm}$ \\
\hline Methyl Mercaptan & 0.5 & $0.5^{* *}$ & 25 & 100 & $\mathrm{ppm}$ \\
\hline Monomethylamine & 10 & 10 & 100 & 500 & $\mathrm{ppm}$ \\
\hline Monomethylhydrazine (Ca) & 0.24 & & 0.5 & 50 & $\mathrm{ppm}$ \\
\hline Nickel Carbonyl (as Ni) (Ca) & 0.001 & $0.05^{*}$ & 0.05 & 7 & $\mathrm{ppm}$ \\
\hline Nitric Acid & 2 & (2) & (15) & (30) & $\mathrm{ppm}$ \\
\hline Nitrogen Dioxide & $2^{*}$ & (2) & (15) & $(30)$ & $\mathrm{ppm}$ \\
\hline Nitrous Oxide & 50 & 150 & 10000 & 20000 & $\mathrm{ppm}$ \\
\hline Ozone & 0.1 & 0.3 & 1 & 10 & $\mathrm{ppm}$ \\
\hline Perchloroethylene & 25 & 100 & 200 & 500 & $\mathrm{ppm}$ \\
\hline Perfuoroisobutylene & & & 0.1 & 0.3 & $\mathrm{ppm}$ \\
\hline Phenol & 5 & 10 & 50 & 200 & $\mathrm{ppm}$ \\
\hline Phosgene & 0.1 & $0.2^{*}$ & 0.2 & 1 & $\mathrm{ppm}$ \\
\hline Phosphine & 0.3 & 1 & $(50)$ & $(100)$ & $\mathrm{ppm}$ \\
\hline Phosphoric Acid & 1 & $\overline{3}$ & 5 & 10000 & $\mathrm{mg} / \mathrm{m} 3$ \\
\hline Phosphorous Pentoxide & & 5 & 25 & 100 & $\mathrm{mg} / \mathrm{m} 3$ \\
\hline Sodium Hydroxide & & (2) & $(40)$ & $(100)$ & $\mathrm{mg} / \mathrm{m} 3$ \\
\hline Sodium Monoxide & & & & & $\mathrm{mg} / \mathrm{m3}$ \\
\hline Sodium Peroxide & & & & & $\mathrm{mg} / \mathrm{m} 3$ \\
\hline Styrene (Ca) & 50 & 100 & 200 & 500 & $\mathrm{ppm}$ \\
\hline Sulfur Dioxide & $0.3^{*}$ & 0.3 & 3 & 15 & $\mathrm{ppm}$ \\
\hline $\begin{array}{l}\text { Sulfuric Acid (Oleum, Sulfur } \\
\text { Trioxide) }\end{array}$ & 1 & 2 & 10 & 30 & $\mathrm{mg} / \mathrm{m} 3$ \\
\hline Tetrafluoroethylene & & 200 & 1000 & 10000 & $\mathrm{ppm}$ \\
\hline Titanium Tetrachloride & & 5 & 20 & 100 & $\mathrm{mg} / \mathrm{m} 3$ \\
\hline Toluene & 100 & 150 & 300 & 2000 & $\mathrm{ppm}$ \\
\hline Trichloroethylene (Ca) & 50 & $(100)$ & $(500)$ & $(1000)$ & $\mathrm{ppm}$ \\
\hline
\end{tabular}




\begin{tabular}{|l|c|c|c|c|c|}
\hline CHEMICAL NAME & PEL-TWA & ERPG-1 & ERPG-2 & ERPG-3 & UNITS \\
\hline Trichlorofluoromethane (FC11) & 100 & & 1500 & 10000 & $\mathrm{ppm}$ \\
\hline Trichlorotrifluroethane (FC113) & 1000 & 1250 & 1500 & 4500 & $\mathrm{ppm}$ \\
\hline Trimethylamine & 10 & $10^{* *}$ & 100 & 500 & $\mathrm{ppm}$ \\
\hline Uranium Hexafluoride & 0.2 & $(1)$ & $(10)$ & $(20)$ & $\mathrm{ppm}$ \\
\hline Vinyl Acetate & $5^{*}$ & 5 & 75 & 500 & $\mathrm{ppm}$ \\
\hline Vinylidene Chloride & 1 & $10^{*}$ & 10 & & $\mathrm{ppm}$ \\
\hline Xylene & 100 & 150 & 200 & 1000 & $\mathrm{ppm}$ \\
\hline \hline Number of Guideline Values & 74 & 78 & 85 & 79 & \\
\hline
\end{tabular}

Note: Bold numbers are ERPG values, bold numbers in parentheses are draft ERPG values, numbers in bold itallics are new.

Notes for Table A-1: Chemical-Specific or hierarchy-based Alternative Concentrations:

Values given as alternatives in the absence of ERPG values were selected from the concentration-limit parameters using the hierarchy presented in Table 4.

(Ca) indicates that chemical is a confirmed or suspected human carcinogen.

At least one guideline value was found for all but 2 (sodium monoxide and sodium peroxide) of the 88 chemical substances on this list. Neither is listed among over 2000 chemicals on the ILO-CIS data base of exposure limits (ILO 1991). Values from 15 major countries are included in this list. It is concluded that the above two substances do not qualify as being "extremely hazardous".

* Values adjusted downwards to next higher range value. For example, the PEL-STEL for isopropyl alcohol is $500 \mathrm{ppm}$, whereas the EEGL-60 is $400 \mathrm{ppm}$. Therefore, the ERPG-1-equivalent value is adjusted downwards to $400 \mathrm{ppm}$.

* For three chemicals, ERPG-1 values that are odor-based have been adjusted upwards. The higher PEL-STEL is used instead of the ERPG-1 value because the ERPG-1 value is based on perception rather than health effects. ERPG-1 values for compounds like carbon disulfide and sulfur dioxide could also have been adjusted upwards, but since the adjustment was small (less than a factor of 10), this was not done. For each of the three chemicals below, the adjustment involved a factor of 100. Without adjustment, the hierarchy values for hydrogen sulfide, methyl mercaptan, and trimethylamine would have been as follows:

\begin{tabular}{||l|l|l|l|l|l||}
\hline \hline Chemical & Formula & $\begin{array}{l}\text { TLV-TWA } \\
(\mathrm{ppm})\end{array}$ & $\begin{array}{l}\text { ERPG-1 } \\
(\mathrm{ppm})\end{array}$ & $\begin{array}{l}\text { ERPG-2 } \\
(\mathrm{ppm})\end{array}$ & $\begin{array}{l}\text { ERPG-3 } \\
(\mathrm{ppm})\end{array}$ \\
\hline $\begin{array}{l}\text { Hydrogen } \\
\text { Sulfide }\end{array}$ & $\mathrm{H} 2 \mathrm{~S}$ & 10 & $(0.1)$ & 30 & 100 \\
\hline $\begin{array}{l}\text { Methy] } \\
\text { mercaptan }\end{array}$ & $\mathrm{CH} 3 \mathrm{SH}$ & 0.5 & $(0.005)$ & 15 & 100 \\
\hline $\begin{array}{l}\text { Trimethy }- \\
\text { amine }\end{array}$ & $(\mathrm{CH} 3) 3 \mathrm{~N}$ & 10 & $(0.1)$ & 1500 & 4500 \\
\hline
\end{tabular}

Note: The ERPG-1 values that have been adjusted, using the hierarchy values from Table A-2, are in parentheses. 
Table A-2

Recommended Hierarchy of Alternative Concentration-Limit Parameters

\begin{tabular}{||l|l|l|l||}
\hline Primary Guideline & $\begin{array}{l}\text { Hierarchy } \\
\text { Group }\end{array}$ & $\begin{array}{l}\text { Hierarchy of } \\
\text { Alternative } \\
\text { Guidel ines }\end{array}$ & $\begin{array}{l}\text { Source of } \\
\text { Concentration } \\
\text { Parameter }\end{array}$ \\
\hline ERPG-3 & 1 & $\begin{array}{l}\text { EEGL }(30-\text { min) } \\
\text { IDLH }\end{array}$ & $\begin{array}{l}\text { AIHA 1991 } \\
\text { NAS 1985 } \\
\text { NIOSH 1990 }\end{array}$ \\
\hline ERPG-2 & 2 & $\begin{array}{l}\text { EEGL }(60-\text { min) } \\
\text { LOC } \\
\text { PEL-C } \\
\text { TLV-C } \\
\text { TLV TWA } \times 5 *\end{array}$ & $\begin{array}{l}\text { AIHA 1991 } \\
\text { NAS 1985 } \\
\text { EPA 1987 } \\
\text { CFR 29:1910.1000 } \\
\text { ACGIH 1992 } \\
\text { ACGIH 1992 }\end{array}$ \\
\hline ERPG-1 & 3 & $\begin{array}{l}\text { PEL-STEL } \\
\text { TLV-STEL } \\
\text { TLV-TWA } \times 3 *\end{array}$ & $\begin{array}{l}\text { AIHA 1991 } \\
\text { CFR 29:1910.1000 } \\
\text { ACGIH 1992 } \\
\text { ACGIH 1992 }\end{array}$ \\
\hline PEL-TWA & 4 & $\begin{array}{l}\text { CFR 29:1910.1000 } \\
\text { ACGIH 1992 } \\
\text { NAS 1985 } \\
\text { NAS 1985 }\end{array}$ \\
\hline & $\begin{array}{l}\text { TLV-TWA } \\
\text { SPEGL (60-min) } \\
\text { CEGL }\end{array}$ \\
\hline
\end{tabular}

Notes: * Applicable only to chemicals whose effects are dose-dependent.

The protocol is to use the primary guidelines first and then the alternative guidelines in the order presented for each hazard level when the primary guideline does not exist.

If application of this hierarchy to a particular chemical gives rise to a value for a lower hazard class that is higher than the value for the next higher hazard class (e.g., ERPG-1-equivalent value greater than ERPG-2-equivalent value), then that value should be adjusted downwards to match that of the next higher hazard class (see Table A-1 for examples).

\section{References:}

WSRC 1993

"Toxic Chemical Hazard Classification and Risk Acceptance Guidelines for use in D.O.E. Facilities", Recommendations of the Westinghouse M \& 0 Nuclear Facility Safety Committee Subcommittee on Nonradiological Risk Acceptance Guidelines Development, (April 20, 1993), WSRC-MS-92-206, REV. 1 


\section{Appendix B}

Development of Plume Distance Nomograph for Protective action 


\section{Introduction}

The protective action nomograph used for determining chemical plume distance was developed by placing several three line nomographs together to predict the centerline plume distance. The nomograph scales on the lines are all

logarithmic so the values can be multiplied or divided as required in the gaussian plume equation.

\section{II.Plume Distance Equations}

The various equations used to construct the NOMOGRAPH EQUATION were taken from the EPA/FEMA/DOT "Technical Guidance to Hazards Analysis - Emergency Planning for Extremely Hazardous substance" (EPA 1987). They are presented in Table B1. The LIQUID FACTORS equation contains the chemical specific parameters relevant to a pool evaporation generation of vapors. The DIKED AREAS equation is used because the surface area of the liquid pool is known. The STEADY STATE CONCENTRATION DOWNWIND equation relates the generation rate to the chemical air concentration and the Pasquill stability (meteorological factors). The UNIT CONVERSION equations convert units in the various equation to common units. The PASQUILL STABILITY equations and the constants were solved in terms of the other variables in the NOMOGRAPH EQUATION Tiquid pool and mass release scenarios. Table B-2 contains the value for various distances of the PASQUILL STABILITY equations pTus the value of the 7 inearized constant ( 7.9836 for the liquid pool release and -3.8451 for the mass release).

The constant term includes the numerical value of the constants from the various equations and the temperature factor of $\left(273^{\circ} \mathrm{C}+\mathrm{T} 1\right)$ where $\mathrm{T} 1$ is set to $27^{\circ} \mathrm{C}$. A temperature of $27^{\circ} \mathrm{C}$ was used because it is the temperature associated with the 95\% weather at the ICPP and when added to $273^{\circ} \mathrm{K}$ it gives $300^{\circ} \mathrm{K}$. The temperature was included in the constant because most degree changes would produce very small changes in the nomograph equation results due to the large $273^{\circ} \mathrm{K}$ value added to each temperature used. The $27^{\circ} \mathrm{C}$ would produce conservative results for conditions below $27^{\circ} \mathrm{C}$ at the ICPP.

The STEADY STATE DOWNWIND equation is good for downwind plumes releases from 10 minutes to 1 hour. The PASQUILL STABILITY equations are Timited for use with distances ranging from $100 \mathrm{~m}$ to $10,000 \mathrm{~m}$. The open country equations were selected because the site is located in open desert country. The $A$ stability equation is used for clear days when there are no clouds in the sky or less than $10 \%$ cloud cover. The D stability equation is for cloudy (more than $10 \%$ cloud cover) days or nights. The $F$ stability equation is used for clear (less than $10 \%$ cloud cover) nights. The stability equations provide an one hour average concentration. The HANNA CORRECTION FACTOR from "Handbook of Atmospheric Diffusion," (DOE/TIC-11223 1982) was used to adjust the concentration to a 15 minute average plume peak. 
Table B-1. Nomograph Equations

\begin{tabular}{|c|c|c|}
\hline $\begin{array}{l}\text { EQUATION } \\
\text { FACTOR }\end{array}$ & EQUATION & EPA 1987 \\
\hline $\begin{array}{l}\text { LIQUID } \\
\text { FACTORS }\end{array}$ & LFA $=\left(0.106 \times u^{0.78} \times M H^{23} \times 0.49 \times Q S \times V P\right) /(82.05 \times(T 1+273))$ & 10 \\
\hline DIKED AREAS & $Q R_{\mathrm{Ib} / \min }=\left(L F A \times\left(A \mathrm{ft}^{2}\right) \times u^{0.78}\right) / 0.49$ & 14 \\
\hline $\begin{array}{l}\text { STEADY STATE } \\
\text { CONCENTRATION } \\
\text { DOWNWIND }\end{array}$ & $\left(C \mathrm{gm} / \mathrm{m}^{3}\right)=Q R_{\mathrm{g} / \mathrm{sec}} /(\mathrm{Pi} \times \sigma-y \times \sigma-z \times \mathrm{u})$ & 15 \\
\hline $\begin{array}{l}\text { UNIT } \\
\text { CONVERSION }\end{array}$ & $Q R_{\mathrm{lb} / \mathrm{min}}=0.132 \times Q R_{\mathrm{g} / \mathrm{sec}}$ & NA \\
\hline $\begin{array}{l}\text { UNIT } \\
\text { CONVERSION }\end{array}$ & $\left(\mathrm{Cmg} / \mathrm{m}^{3}\right)=1 / 1000 \times\left(\mathrm{c} \mathrm{gm} / \mathrm{m}^{3}\right)$ & NA \\
\hline $\begin{array}{l}\text { PASQUILL A } \\
\text { STABILITY } \\
\text { (OPEN } \\
\text { COUNTRY) }\end{array}$ & $\sigma-y \sigma-z=\left(0.22 d(1+0.0001 d)^{-1 / 2}\right)(0.20 d)$ & $\begin{array}{l}\text { EXHIBIT } \\
G-1\end{array}$ \\
\hline $\begin{array}{l}\text { PASQUILL D } \\
\text { STABILITY } \\
\text { (OPEN } \\
\text { COUNTRY) }\end{array}$ & $\sigma-y \sigma-z=\left(0.08 d(1+0.0001 d)^{-1 / 2}\right)\left(0.06 d(1+0.0015 d)^{-1 / 2}\right)$ & $\begin{array}{l}\text { EXHIBIT } \\
G-1\end{array}$ \\
\hline $\begin{array}{l}\text { PASQUILL F } \\
\text { STABILITY } \\
\text { (OPEN } \\
\text { COUNTRY) }\end{array}$ & $\sigma-y \sigma-z=\left(0.04 d(1+0.0001 d)^{-1 / 2}\right)\left(0.016 d(1+0.0003 d)^{-1}\right)$ & $\begin{array}{l}\text { EXHIBIT } \\
G-1\end{array}$ \\
\hline $\begin{array}{l}\text { HANNA } \\
\text { CORRECTION } \\
\text { FACTOR }\end{array}$ & $\left(15_{\min } / 60_{\min }\right)^{.02}=0.7579$ & NA \\
\hline $\begin{array}{l}\text { LIQUID POOL } \\
\text { NOMOGRAPH } \\
\text { EQUATION }\end{array}$ & $(\sigma-y \sigma-z)(43.7718)(.7579)=M W^{2 / 3} \times$ VP $\times A_{S O F T} \times u^{-.22} \times\left(C M G / M^{3}\right)^{-1}$ & \\
\hline $\begin{array}{l}\text { LIQUID POOL } \\
\text { LINEARIZED } \\
\text { NOMOGRAPH } \\
\text { EQUATION }\end{array}$ & $\operatorname{LOG}(\sigma-y \sigma-z)+1.5208=\operatorname{LOG}\left(M W^{\wedge}(2 / 3)\right)+\operatorname{LOG}(V P)+\operatorname{LOG}\left(A_{s q}\right)-.22 \operatorname{LOG}(u)-\operatorname{LOG}\left(C \mathrm{mg} / \mathrm{m}^{3}\right)$ & \\
\hline
\end{tabular}




\begin{tabular}{|c|c|c|}
\hline $\begin{array}{l}\text { EQUATION } \\
\text { FACTOR }\end{array}$ & EQUATION & EPA 1987 \\
\hline $\begin{array}{l}\text { MASS RELEASE } \\
\text { RATE } \\
\text { NOHOGRAPH } \\
\text { EQUATION }\end{array}$ & $(\sigma-y \sigma-z)\left(1.88 \times 10^{-4}(0.7579)=Q R_{k g / \text { in }} \times u^{-1} \times\left(C \mathrm{mg} / \mathrm{m}^{3}\right)^{-1}\right.$ & \\
\hline $\begin{array}{l}\text { MASS RELEASE } \\
\text { RATE } \\
\text { NOWOGRAPH } \\
\text { EQUATION }\end{array}$ & $\operatorname{LOG}(\sigma-y \sigma-z)-3.8451=\operatorname{LOG}\left(Q_{k g} R_{\text {min }}\right)-\operatorname{LOG}(u)-\operatorname{LOG}\left(\mathrm{Cmg} / \mathrm{m}^{3}\right)$ & \\
\hline
\end{tabular}

WHERE:

$\mathrm{QR}_{\mathrm{Ib} / \mathrm{min}}=$ Rate of release to air (lb/min)

$Q R_{\mathrm{gm} / \mathrm{sec}}=$ Rate of release to air $(\mathrm{gm} / \mathrm{sec})$

$\mathrm{MH}=$ Molecular weight (g/g-moles)

$A \mathrm{ft}^{2}=$ surface area of spilled material $\left(\mathrm{ft}^{2}\right)$

VP = Vapor pressure of material ( $\mathrm{mm} \mathrm{hg}$ )

$82.05=R$ of 82.05 atm $\mathrm{cm}^{\wedge} 3 / \mathrm{g}$-mole $K$

$T I=27^{\circ} \mathrm{C}$ simplification for Horst case weather condition

$u=$ Windspeed $(\mathrm{m} / \mathrm{sec})$

QS = Quantity spilled (lbs)

C $\mathrm{gm} / \mathrm{m}^{3}=$ Airborne concentration $\left(\mathrm{gm} / \mathrm{m}^{3}\right)$

C $\mathrm{mg} / \mathrm{m}^{3}=$ Airborne concentration $\left(\mathrm{mg} / \mathrm{m}^{3}\right)$

$d=$ Centerline plume distance $(m)$

$P_{j}=3.141$

$\sigma-y=$ Dispersion deviation horizontally $(m)$

$\sigma-z$ Dispersion deviation vertically (m) 
Table B-2. Stability Equation and Constant Values

\begin{tabular}{l|l|l|l|l}
\hline DISTANCE, M & $\sigma-y \quad \sigma-z$ & LOG $(\sigma-y \quad \sigma-z)$ & $\begin{array}{l}\text { INCLUDING } \\
\text { CONSTANT } \\
\text { (LIQUID } \\
\text { POOL) }\end{array}$ & $\begin{array}{l}\text { INCLUDING } \\
\text { CONSTANT } \\
\text { (MASS } \\
\text { RELEASE) }\end{array}$ \\
\hline \hline
\end{tabular}

F STABILITY FACTOR OPEN COUNTRY

\begin{tabular}{r|r|r|r|r}
\hline 100 & 6.18276 & 0.7912 & 2.3120 & -3.0539 \\
\hline 1000 & 469.3970 & 2.6715 & 4.1923 & -1.1736 \\
\hline 10000 & 11313.7085 & 4.0536 & 5.5744 & 0.2085 \\
\hline
\end{tabular}

D STABILITY FACTOR OPEN COUNTRY

\begin{tabular}{r|r|r|r|r}
\hline 100 & 44.5381 & 1.6487 & 3.1695 & -2.1964 \\
\hline 1000 & 2894.5089 & 3.4616 & 4.9824 & -0.3835 \\
\hline 10000 & 84852.8137 & 4.9287 & 6.4494 & 1.0836 \\
\hline
\end{tabular}

A STABILITY FACTOR OPEN COUNTRY

\begin{tabular}{r|r|r|r|r}
\hline 100 & 437.81649 & 2.6413 & 4.1621 & -1.2038 \\
\hline 1000 & 41952.3539 & 4.6228 & 6.1435 & 0.7776 \\
\hline 10000 & 3111269.8372 & 6.4929 & 8.0137 & 2.6478 \\
\hline
\end{tabular}




\section{III.Nomograph Patterns}

Several three line nomographs were used to complete mathematical operations graphically. The three line nomograph has three vertical lines equally spaced. Input variable of the nomograph equation are located on the left two lines and the resultant calculation on the right most line. The calculation is completed by marking the value of input variables on the left two lines and connecting and projecting with a straight ruler to the right most line for the results. When connecting several nomographs in series the resultant line becomes the "tie line" to the next nomograph. Tie lines on nomographs typically do not show the calculated values, because the tie line is the first input line on a following three line nomograph. By restricting the distances between the nomograph 7 ines to equal distances, the middle line linear increments used to construct the scales are always half the size of increments of the lines on either side. In the liquid pool release nomograph some of the three line nomographs were reduced in size to fit on the page. In this case two tie lines were placed next to each other with connecting lines from the first tie line to the next to guide the transition to a different scale three line nomograph.

The nomograph used in this project combines a series of three nomographs. Each three line nomograph will be called a nomograph patterns in this discussion. The liquid pool nomograph shown in figure B-1 combines four nomograph patterns. The mass release nomograph combines two nomograph patterns. Each nomograph starts at the Teft and finishes on the right. 
Figure B-1 Protective action Plume Distance Nomograph

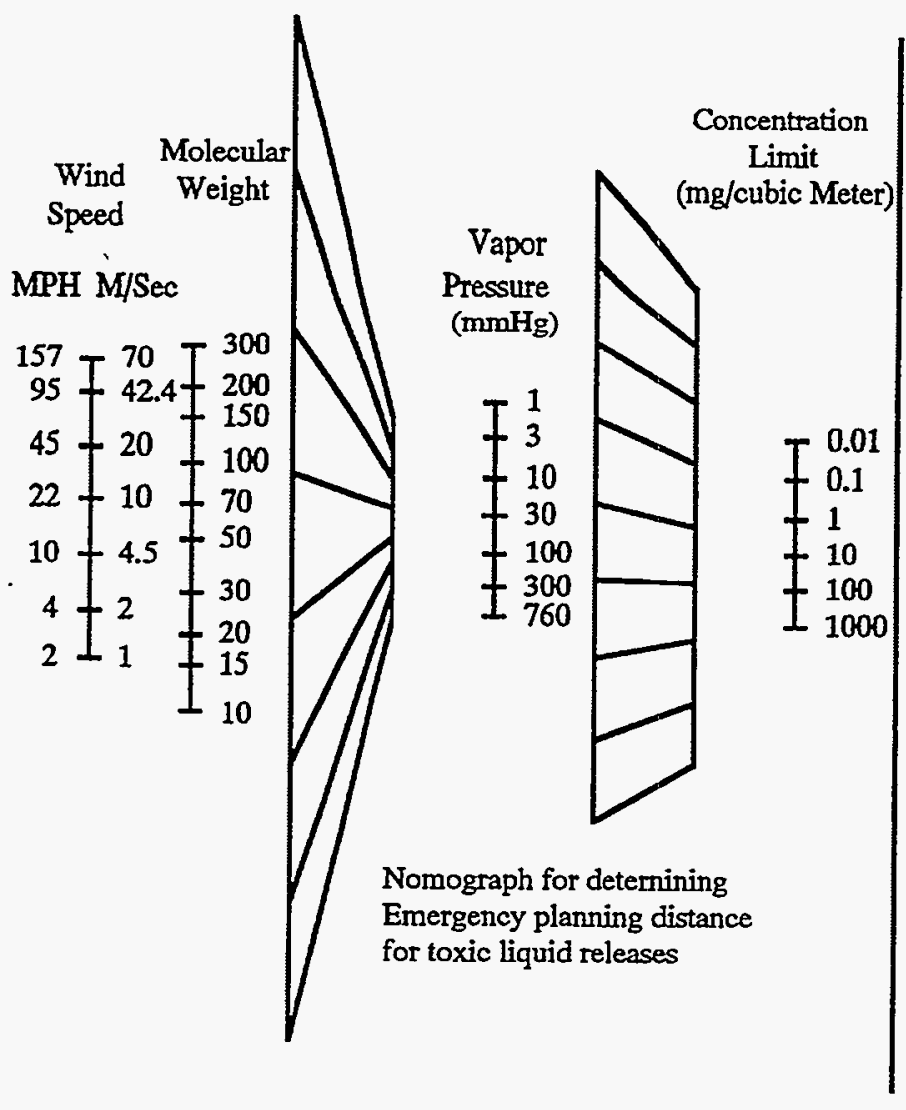

Distance

(Meters)

Area of
Spill

Sq Ft Sq M

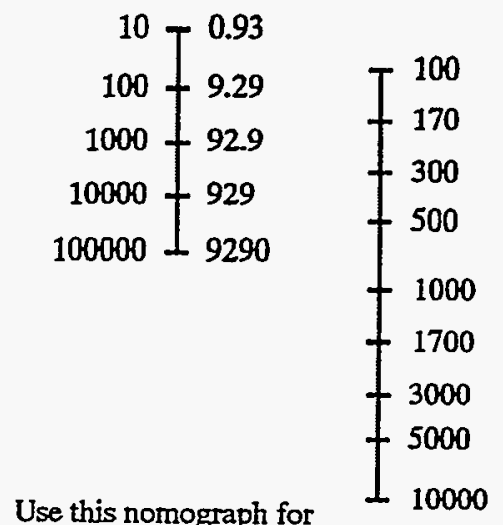

Use this nomograph for

sky conditions of stability

class "A" (Daytime - Clear)

Figure 4 
Three patterns were used in the construction of the liquid pool release protective action plume distance nomograph and two patterns were used in the mass release nomograph. These patterns include a multiplication pattern and two division patterns. The multiplication pattern was used for vapor pressure and area multiplication in the liquid pool nomograph. A division pattern was used to divide the chemical concentration into previous calculations in both the liquid pool nomograph and the mass release nomographs. Another division pattern was used to divide the wind speed raised to a fractional power into the molecular weight raised to a fractional power in the liquid pool nomograph and to divide the wind speed into the mass release rate in the mass release nomograph.

In the multiplication pattern, the values for each multiplicand was placed on the left and center lines with the resultant calculation on the tie line. Unique to the multiplication pattern, the center and right line scales are opposite in increasing magnitude relative to the left line scale. In other words if the scale on the left line increases going vertically up the line then the values on the middle and right lines must decrease while moving up the lines.

For the first division pattern, the divisor values are place on the middle line of the three line nomograph pattern, the numerator values on the left line, and the resultant calculated on the right line. Unique to this division pattern, the values on the left and middle lines increased in magnitude in the same direction while the values on the right line decrease.

The second division pattern has the divisor values on the left line, the numerator values on the center line, and the resultant value on the right Tine. Unique to this pattern, all values increase in magnitude in the same direction on each 7 ine. The variables used in this pattern (wind speed and molecular weight) are raised to a power in the nomograph equation. These values were scaled before placing the values on the lines.

For figure $B-1$, the wind speed, $u$, raised to the 0.22 power on the first left line was divided into the molecular weight raised to the $2 / 3$ rd power on the second line using the second division pattern to give the resultant value on the tie line. This tie line was scaled down so the next pattern could be shown on the page. The next line contains the vapor pressure which is multiplied with a resultant on the tie line using the multiplication pattern. This tie line is scaled down before dividing by the chemical airborne concentration, $C$, on the next line using the first division pattern with results on the next tie line. This tie line does not need to be scaled down before multiplying by the area of the spi11, A, to project the resultant stability classification distance on the last line. The log of the $A$ Stability class value includes the constant from the nomograph equation which is used to Tocate the distance for the chemical plume.

For the mass release nomograph, the wind speed on the first line is divided into the mass release rate on the second line using the second division pattern. The resultant is the tie line or third ine on the nomograph. The concentration on the fourth line is divided into the tie line using the first division pattern to give the resultant stability class distance on the last line of the nomograph.

The plotting tolerance can be as much $10 \%$ because the errors are only additive 
due to the logarithmic or power nature of the scales. The RMS result of these combined errors is between 22 and $26 \%$. With the inherent uncertainty of plume calculation models this should be acceptable.

\section{References:}

EPA 1987 U.S. Environmental Protection Agency, Federal Emergency Management agency, U.S. Department of Transportation, "Technical Guidance for Hazards Analysis - Emergency Planning for Extremely Hazardous Substances," December 1987. 


\section{Appendix C}

Acronym Definitions 
AGENCIES: (Listed alphabetically)

ACGIH American Conference of Governmental Industrial Hygienists

AIHA

EPA

FEMA

American Industrial Hygiene Association

NAS

NIOSH

OSHA

USDOT

Environmental Protection Agency

Federal Emergency Management Agency

National Academy of Sciences

National Institute for Occupational Safety and Health

Occupational Safety \& Health Administration

GUIDELINES

AIHA Terms (developed for emergency response purposes) (AIHA 1989):

ERPG-1 Emergency Response Planning Guidel ine 1: "The maximum airborne concentration below which it is believed that nearly all individuals could be exposed for up to 1 hour without experiencing other than mild transient adverse health effects or perceiving a clearly defined objectionable odor."

ERPG-2 Emergency Response Planning Guideline 2: "The maximum airborne concentration below which it is believed that nearly all individuals could be exposed for up to 1 hour without experiencing or developing irreversible or other serious health effects or symptoms that could impair their abilities to take protective action."

ERPG-3 Emergency Response PT anning Guidel ine 3: "The maximum airborne concentration below which it is believed nearly all individuals could be exposed for up to 1 hour without experiencing or developing life threatening health effects."

NAS Terms (developed for military use) (NAS 1986):

EEGL Emergency Exposure Guidance Level "A concentration of a substance in air (as a gas, vapor, or aerosol) that may be judged by DOD to be acceptable for the performance of specific tasks during rare emergency conditions lasting for periods of 1-24 h. Exposure at an EEGL might produce reversible effects that do not impair judgement and do not interfere with proper responses to the emergency". The EEGL is "a ceiling guidance level for a single emergency exposure, usually lasting from $1 \mathrm{~h}$ to $24 \mathrm{~h}$-- an occurrence expected to be infrequent in the lifetime of a person".

CEGL Continuous Exposure Guidance Level: "CEGLs are ceiling concentrations designed to avoid adverse health effects, either immediate or delayed, of more prolonged exposures and to avoid degradation in crew performance that might endanger the objectives of a particular mission as a consequence of continuous exposure for up to 90 days". 
SPEGL Short-Term Public Emergency Guidance Level: "The SPEGL is defined as a suitable concentration for unpredicted, single, short-term, emergency exposure of the general public. In contrast to the EEGL, the SPEGL takes into account the wide range of susceptibility of the general public. This includes sensitive populations -- such as children, the aged, and persons with serious debilitating diseases".

OSHA Terms (developed for occupational safety) (CFR 29:1910.1000):

PEL Permissible Exposure Limit: Although the term PEL is not used in the "Final Rule Limits Columns" of Table Z-1-A and Table Z-2, it was used in the "Transitional Limits". It is also used in the compound-specific rules for various substances, e.g., \#1910.1018 (Inorganic arsenic), \#1910.1028 (Benzene), \#1910.1045 (Acrylonitrile), \#1910.1047 (Ethylene oxide), etc.

PEL-TWA Time-Weighted Average: "The employee's average airborne exposure in any 8-hour work shift of a 40 -hour work week which shall not be exceeded". This is to be computed from the equation: $E=(\mathrm{CaTa}+\mathrm{CbTb}+\ldots \mathrm{CnTn}) / 8$ where $C$ is the concentration during any period of time $T$ (in hours) where the concentration remains constant.

PEL-STEL Short-Term Exposure Limit: "The employee's 1-minute time weighted average exposure which shal 1 not be exceeded at any time during a work day unless another time limit is specified ...".

PEL-C Ceiling: "The employee's exposure which shall not be exceeded during any part of the work day". If necessary from a monitoring point of view, C may be assessed as a 15-minute time weighted average.

EPA Terms (developed for emergency planning) (EPA 1987):

LOC Level of Concern: "The concentration of an extremely hazardous substance in air above which there may be serious irreversible health effects or death as a result of a single exposure for a relatively short period of time." (ATso used by FEMA and US DOT) 
ACGIH Terms (developed for workplace safety) (ACGIH 1992):

TLV-TWA Threshold Limit Value - Time-Weighted Average: "The time-weighted average concentration for a normal 8-hour workday and a 40-hour workweek, to which nearly a17 workers may be repeatedly exposed, day after day, without adverse effect."

TLV-STEL Threshold Limit Value - Short-Term Exposure Limit: "The concentration to which workers can be exposed continuously for a short period of time without suffering from 1) irritation, 2) chronic or irreversible tissue damage, or 3) narcosis of sufficient degree to increase the likelihood of accidental injury, impair self-rescue, or materially reduce work efficiency, and provided that the dai7y TLV-TWA is not exceeded." "A TLV-STEL is ...a ... 15-minute TWA exposure which should not be exceeded at any time during a workday even if the 8-hour TWA is within the TLV-TWA. Exposures above the TLV-TWA up to the STEL should not be Tonger than 15 minutes and should not occur more than four times per day. There should be at least 60 minutes between successive exposures in this range."

TLV-C Threshold Limit Value - Ceiling: "The concentration that should not be exceeded during any pan of the working exposure." "... if instantaneous monitoring is not feasible, then the TLV-C can be assessed by sampling over a 15-minute period except for those substances that may cause immediate irritation when exposures are short."

NIOSH Terms (developed for respirator use) (NIOSH 1990):

IDLH Immediately Dangerous to Life or Health: "The maximum concentration from which, in the event of respirator failure, one could escape within 30 minutes without a respirator and without experiencing any escape impairing (e.g., severe eye irritation) or irreversible health effects." 


\section{References:}

ACGIH 1992

AIHA 1989

AIHA 1991

CFR $40: 302$

CFR 29:1910.1000

CFR 29:1910.119

EPA 1987

NAS 1986

NIOSH 1987
"Threshold Limit Values for Chemical Substances and Physical Agents and Biological Exposure Indices", American Conference of Governmental Industrial Hygienists, Cincinnati, OH, (1992 - 1993)

"Concepts and Procedures for the Development of Emergency Response Planning Guidelines (ERPGs)", American Industrial Hygiene, Association ERPG Committee, (December 1989). (New data sets issued as they are developed).

"Emergency Response Planning Guidelines", American Industrial Hygiene Association ERPG Committee, "American Industrial Hygiene Association, Akron, OH (1991).

"List of Hazardous Substances and Reportable Quantities", Code of Federal Regulations: Protection of Environment, 40 CFR Part 302. Table 302.4, pp. 228-298 (7-1-91 Edition).

"Toxic and Hazardous Substances, Air Contaminants", Code of Federal Regulations: Labor: 29: Part 1910.1000, Subpart Z pp 6-33, (Revised as of JuTy 1,1990).

"Process Safety Management of Highly Hazardous Chemicals; Explosives and Blasting Agents; Final Rule. Appendix A List of Highly Hazardous Chemicals, Toxics and Reactives", Code of Federal Regulations: Labor: 29 Part 1910.119, (February 24, 1992).

"Emergency Planning for Extremely Hazardous Substances", Technical Guidance for Hazard Analysis, U.S. Environmental Protection Agency, Federal Emergency Management Agency; and U.S. Department of Transportation, USGPO 1991 517-003/47004, (December 1987).

"Guidelines and Methods for Preparing Emergency Exposure Guidance Level (EEGL), Short-Term Public Emergency Guidance Level (SPEGL), and Continuous Exposure Guidance Level (CEGL) Documents", COMMITTEE ON TOXICOLOGY, Board on Environmental Studies and Toxicology, Commission on Life Sciences, National Research Council. National Academy Press, Washington DC (1986).

"NIOSH POCKET GUIDE TO CHEMICAL HAZARDS", U.S. Department of Health and Human Services, Public Health Service, Centers for Disease Control, National Institute for Occupational Safety and Health, Washington DC (1990). 
Appendix D

Example Solutions of Nomographs 
Spill conditions and variable inputs:

Wind speed of $4 \mathrm{mph}$

Molecular weight of $50 \mathrm{~g}$-moles

Vapor pressure of $760 \mathrm{~mm} \mathrm{Hg}$

Concentration in air of $1 \mathrm{mg} / \mathrm{m}^{3}$

Spill area of $1000 \mathrm{ft}^{2}$

Sky contition is daytime - clear

The spill site wind speed, chemical molecular weight, chemical vapor pressure, chemical air concentration 1 imit, and area of the spill are require for inputs to the nomograph. The nomograph for day - clear liquid spill (Figure 4) was selected. For this hypothetical chemical spill scenario the resultant plume distance would be less than 3000 meters.

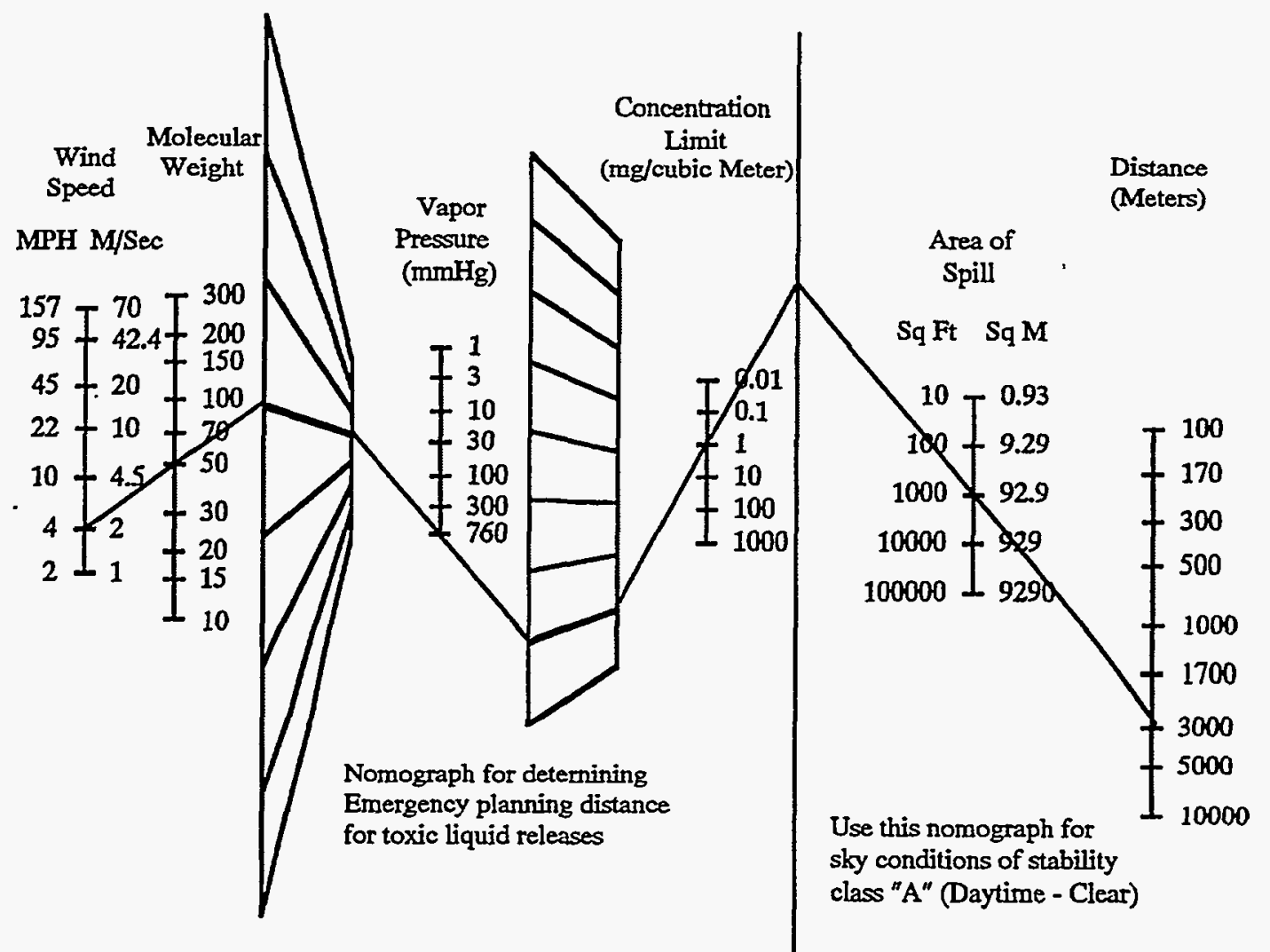

Figure 4 